\title{
Driven to Distraction: Extraneous Events and Underreaction to Earnings News
}

\author{
DAVID HIRSHLEIFER, SONYA SEONGYEON LIM, and SIEW HONG TEOH*
}

\begin{abstract}
Recent studies propose that limited investor attention causes market underreactions. This paper directly tests this explanation by measuring the information load faced by investors. The investor distraction hypothesis holds that extraneous news inhibits market reactions to relevant news. We find that the immediate price and volume reaction to a firm's earnings surprise is much weaker, and post-announcement drift much stronger, when a greater number of same-day earnings announcements are made by other firms. We evaluate the economic importance of distraction effects through a trading strategy, which yields substantial alphas. Industry-unrelated news and large earnings surprises have a stronger distracting effect.
\end{abstract}

[Attention] is the taking possession by the mind in clear and vivid form, of one out of what seem several simultaneously possible objects or trains of thought... It implies withdrawal from some things in order to deal effectively with others.

William James, Principles of Psychology, 1890

Almost a quarter of British motorists admit they have been so distracted by roadside billboards of semi-naked models that they have dangerously veered out of their lanes.

Reuters (London), November 21, 2005

IN SEVERAL KINDS of tests, there is on average a delayed price reaction to news that has the same sign as the immediate response. This phenomenon is reflected in the new issue and repurchase puzzles (Loughran and Ritter (1995), Ikenberry,

*Hirshleifer and Teoh are at Paul Merage School of Business, University of California, Irvine and Lim is at Kellstadt Graduate School of Business, DePaul University, Department of Finance, Chicago, Illinois. We thank an anonymous referee; Nick Barberis; Nerissa Brown; Werner DeBondt; Stefano DellaVigna (NBER conference discussant); Laura Field; Wayne Guay (FRA conference discussant); Campbell Harvey (the editor); Christo Karuna; Erik Lie; Yvonne Lu; Ray Pfeiffer (FARS conference discussant); Mort Pincus; Charles Shi; and seminar participants at the Merage School of Business at UC Irvine, DePaul University, the Anderson Graduate School of Management at UCLA, the Sauder School of Business at University of British Columbia, the University of Kansas, and conference participants at the 10th Biennial Behavioral Decision Research in Management Conference at Santa Monica, California, the NBER Behavioral Finance November 2006 Meeting at Cambridge, Massachusetts, the Financial Research Association 2006 Conference at Las Vegas, Nevada, the Financial Accounting and Reporting Section 2007 Conference at San Antonio, Texas, and the Chicago Quantitative Alliance conference at Chicago for very helpful comments. 
Lakonishok, and Vermaelen (1995)), abnormal returns following various types of corporate events such as stock splits and bond ratings changes (Desai and Jain (1997), Dichev and Piotroski (2001)), return momentum (Jegadeesh and Titman (1993)), and post-earnings announcement drift (Bernard and Thomas (1989)). Evidence on stock return lead-lags suggests that information diffuses gradually across industries, between large and small firms, between economically linked firms, and between firms that are followed by different numbers of analysts. ${ }^{1}$ The idea that these phenomena represent irrational underreaction by investors has stimulated a great deal of research and debate.

A recent literature has proposed that limited investor attention offers a possible explanation for these anomalies. Recent theoretical models examine how limited attention can cause underreactions to news as well as other effects on prices. These models predict that investor neglect of information signals can lead to mispricing that is related to publicly available accounting information (Hirshleifer and Teoh (2003), DellaVigna and Pollet (2009)), faster rate of incorporation of information by large than by small stocks (Peng (2005)), neglect of long-term information (DellaVigna and Pollet (2007)), and excessive asset price comovement (Peng and Xiong (2006)).

In the models of DellaVigna and Pollet (2009) and Hirshleifer and Teoh (2005), investors are risk averse, and a subset neglect the information contained in a firm's latest earnings realization about future profitability. In equilibrium stock prices underreact to earnings surprises, so that prices are on average too low after favorable surprises and too high after unfavorable surprises. As a consequence, positive surprises predict high subsequent returns and negative surprises predict low subsequent returns. In other words, there is post-earnings announcement drift.

A comparative statics prediction of limited attention models is that when the amount of attention investors direct toward a firm decreases, there should be more severe underreaction to news about the firm. Several recent papers find that market underreaction is associated with proxies for investor inattention: event occurrence during non-trading hours (Francis, Pagach, and Stephan (1992), Bagnoli, Clement, and Watts (2005)), Fridays (DellaVigna and Pollet (2009)), down market periods (Hou, Peng, and Xiong (2008)), and low trading volume (Hou, Peng, and Xiong (2008)).

Perhaps the most basic comparative statics of the limited attention approach to underreaction anomalies comes from the fact that irrelevant stimuli are distracting. Because minds are finite, attention must be allocated selectively. When individuals try to process multiple information sources or perform multiple tasks simultaneously, performance suffers. Indeed, conscious thought requires a focus on particular ideas or information to the exclusion of others. These elemental facts suggest that an investor's effort to process a news announcement by a firm and understand its implications for profitability can

\footnotetext{
${ }^{1}$ See, e.g., Brennan, Jegadeesh, and Swaminathan (1993), Cohen and Frazzini (2008), Hong, Lim, and Stein (2000), Hong, Torous, and Valkanov (2007), and Hou (2007). Hou and Moskowitz (2005) report that delay-prone firms have anomalous returns.
} 
be hampered by extraneous news events that draw attention toward other firms. Therefore, greater distraction implies more severe underreaction to the firm's earnings news-a weaker immediate reaction to the earnings surprise and stronger post-earnings announcement drift. Intuitively, we also expect that the greater the distraction, the weaker the trading volume response to a news announcement.

Together, we call these predictions the investor distraction hypothesis. We test the investor distraction hypothesis by identifying times when a greater number of public disclosures by other firms compete for investor attention. It is at these times that the immediate price and volume reactions to earnings surprise are predicted to be weaker, and post-earnings announcement drift stronger. Our approach provides a direct test of whether distraction causes market underreactions. It also lends itself to comparative statics tests to identify what kinds of signals are more or less distracting. Such tests help resolve whether limited investor attention explains underreaction anomalies.

The competing news events that we examine are also earnings surprises. Because all publicly traded U.S. firms need to make earnings announcements, earnings surprises provide an extensive sample of distracting events. Of course, earnings announcements by other firms can be relevant for the value of a given test firm. However, even when such information transfer exists, each firm's earnings announcement is typically much more informative about its own value than about the value of other firms. Thus, if attention is limited, earnings announcements by other firms can call investor attention away from the task of valuing the given firm. Such distraction by extraneous news can weaken the market reaction to its earnings surprise.

A key potential concern about our analysis is that the number of earnings announcements on a given day (our measure of distraction) could be determined as a function of (or at least, be correlated with) omitted variables that also affect the stock market reaction to earnings news. For example, the number of earnings announcements is correlated with the calendar period and with delays in earnings releases. We address this concern by verifying our findings after including an extensive set of control variables, using a placebo treatment as an alternative way to control for calendar effects, and examining a subset of firms that announce earnings on both high- and low-distraction days. We discuss this concern in greater detail in Section IV.A.3.

Our study is part of a recent literature that examines how limited attention affects securities markets. Recent empirical work tests whether investors neglect demographic information (DellaVigna and Pollet (2007)) and information in oil prices (Pollet (2005)). Klibanoff, Lamont, and Wizman (1998) find that closed-end country fund prices underreact to shifts in net asset value (NAV), but that reactions are greater when there is salient media publicity about the country. Evidence that the stock market sometimes reacts to previously published news (Ho and Michaely (1988), Huberman and Regev (2001)) suggests that relevant information is neglected at the time of the previous news. Some studies test for limited attention by examining how investors trade in response to public news arrival (see, e.g., Barber and Odean (2008)). 
The prior empirical literature on investor attention has primarily focused on the neglect of public information signals, on the effects of conditions (market return, volume, time-of-day, or day of week) that proxy for lower investor attention, and on how greater publicity draws attention to the firm. A distinctive feature of our paper is that it measures the competing signals that draw investors' attention away from a given news announcement, just as a highway billboard can distract a driver from a pothole. In other words, our aim is to test directly whether extraneous news distracts investors, causing market prices to underreact to relevant news.

For our initial tests of the investor distraction hypothesis, we perform quarterly sorts of stocks based on each firm's earnings surprise, and by the number of earnings announcements by other firms on the same day as the firm's earnings announcement. We call days that are in the top decile for the number of competing announcements "high-news days," as opposed to "low-news days" (bottom decile). We find that investors' announcement date reactions to earnings news are significantly less sensitive to earnings news on high-news days than on low-news days; the interdecile spread of announcement-period abnormal returns between firms with high and low earnings surprises is $7.02 \%$ for low-news days and $5.81 \%$ for high-news days. Similarly, in multivariate regressions that control for the effect of firm characteristics and calendar effects, the announcement date return response is significantly less sensitive to earnings news when there are more competing announcements on the same day. Furthermore, consistent with distraction effects, we find that the abnormal trading volume response to earnings is significantly weaker when the earnings announcement occurs on a high-news day than on a low-news day.

To further test the investor distraction hypothesis, we examine whether postearnings announcement drift is stronger when earnings announcements occur on days with many competing announcements. When we sort stocks based upon the earnings surprise and by the number of competing announcements, we find that the post-earnings announcement drift is much stronger on high-news days. For high-news days, the interdecile spread of the post-announcement 60-day cumulative abnormal returns between high earnings surprise firms and low earnings surprise firms is $7.18 \%$, significant at the $1 \%$ level. The spread is only $2.66 \%$ and marginally significant at the $10 \%$ level for low-news days. Regression analyses also confirm that post-announcement drift is much stronger for earnings announcements made on days with a greater number of competing announcements after controlling for other possible determinants of drift.

In summary, univariate and multivariate tests provide statistically significant evidence that high-news days are associated with a lower sensitivity of announcement abnormal returns to earnings news, a higher sensitivity of postannouncement abnormal returns to earnings news, and a lower trading volume response to earnings news. The effects, which are economically substantial, support the investor distraction hypothesis.

There may be reasons other than distraction why the number of competing announcements affects the sensitivity of returns to earnings. However, as discussed in Section III, it is not entirely clear why this should be the case. 
Furthermore, the distraction hypothesis implies that the number of competing news announcements has opposite effects on the immediate sensitivity of the firm's stock to its earnings surprise, versus the post-event sensitivity. To compete with the distraction hypothesis, any alternative explanation faces the hurdle of explaining these opposite effects. Nevertheless, we consider alternative explanations for our findings and conduct several sensitivity analyses; the results are quite robust.

Another common way of measuring the economic importance of market inefficiencies is to measure the abnormal return performance of portfolio trading strategies. We examine portfolios based on earnings surprises and on the number of distracting news amounts on the days of these surprises. The FamaFrench three-factor alpha associated with the portfolio that is long good earnings news firms and short bad earnings news firms is $1.64 \%$ per month and highly significant for firms announcing on high-news days, but $0.77 \%$ and insignificant for firms announcing on low-news days. These findings indicate that distraction is associated with substantial underreactions.

A key advantage of our approach to testing for limited attention in capital markets is that it permits testing for whether different kinds of competing announcements differ in their distracting effects, and for whether it is easier or harder to distract investors from different kinds of announcements. With regard to different kinds of extraneous news, we compare the distraction effects of industry-unrelated versus industry-related announcements, big versus small earnings surprises, and large versus small firm announcements.

We find that industry-unrelated announcements have a stronger distraction effect than industry-related announcements. This makes sense because a within-industry announcement could potentially call attention toward rather than away from the industry. Also consistent with intuition, we find that big (high absolute value) earnings surprises have a stronger distracting effect than small earnings surprises. This results in significantly greater drift after big earnings surprises by other firms and some hint of a weaker immediate price reaction. A more puzzling finding is that announcements by large firms have a weaker distracting effect than those of small firms. We explore possible explanations, such as that disproportionately more small-firm announcements are extreme surprises compared to those of large firms.

Lastly, we test whether some types of announcements are subject to stronger distraction effects. This is motivated by studies that have documented that the stock market underreacts more to announcements by smaller firms, and that the market reacts differently to positive versus negative surprises (e.g., Basu (1997), Bernard and Thomas (1989)). We discuss reasons to expect distraction effects to differ across announcement types in Section VI.B. For example, if large firms attract so much attention that there is little market underreaction, then distracting information may have limited effect. We find some indication that the distraction effect is stronger for market reactions to earnings announcements by small firms and to positive earnings surprises.

Overall, our evidence on announcement period returns, post-earnings announcement drift, and trading volume responses is generally consistent with 
the investor distraction hypothesis. These findings therefore suggest that limited investor attention affects investor behavior and capital market prices.

The rest of the paper is organized as follows. Section I discusses why distraction can affect market reactions to news. Section II describes the data. Sections III and IV present the univariate and multivariate tests of the investor distraction hypothesis. Section V describes the portfolio trading strategy that exploits the distraction effect, and Section VI examines comparative statics of the distraction effect. Section VII concludes.

\section{Why Distraction Can Affect Market Reactions to News}

\section{A. Psychological Basis for Distraction Effects}

Psychologists have provided a great deal of evidence that it is hard to process multiple information sources or perform multiple tasks at the same time. The interfering effect of extraneous information is illustrated by the famous Stroop task (Stroop (1935)) in which subjects are asked to name the color in which a word is printed when the word does not match its print color, for example, the word "blue" printed in red ink. When the meaning of the word differs from its print color, subjects are slower to name its color, as compared to, for example, naming the color of a geometrical figure.

Selective attention involves the focus (conscious or otherwise) on a portion of a scene or set of stimuli. In some studies of selective attention, individuals are asked to direct their attention toward a stimulus, which interferes with the processing of another. In studies of dichotic listening (Cherry (1953), Broadbent (1958), Moray (1959)), two messages are separately and simultaneously played into a subject's left and right ears using headphones. In some studies, subjects are asked to attend to one of two messages, and "shadow" (repeat back) the words of this message. They are then asked questions about the message they were not attending to. Subjects absorb very little information about the unattended message - whether the voice was male or female, but not what language was spoken or any of the words that were spoken, even if the same word is spoken repeatedly.

In visual studies of selective attention, participants often think that they have absorbed a scene fully when in fact they have only absorbed the subset of details upon which they have focused. Selective attention leads to "change blindness" (whereby a noteworthy change in a visual scene is not noticed; see Simons and Levin (1997)). The phenomenon of "inattentional blindness" involves the failure to perceive task-unrelated stimuli while performing a visual observation task. In such experiments, participants often fail to notice even seemingly conspicuous events in the video scene they are observing-such as a woman walking by in a gorilla suit, stopping, and beating her chest before moving on (Simons and Chabris (1999)).

Studies of divided attention and dual task performance ask participants to attend to multiple stimuli at the same time and to respond to them. In the auditory domain, a dichotic listening experiment can be used to examine the 
effects of divided attention. In such an experiment, subjects can be asked to pay attention to both messages, and later can be asked about the content of each. Studies of dual task performance have found that there is interference between tasks (see, e.g., Pashler and Johnston (1998)), and that performance is much worse when the two tasks are similar, as with tasks involving the same sensory modalities (Treisman and Davies (1973), McLeod (1977)).

In a financial context, the problem of reacting to multiple earnings surprises by revaluing different stocks divides attention, and therefore may also be hard to do. Performing valuations involves using similar kinds of information and types of cognitive processing, potentially leading to interference between tasks. Regardless of whether this is the case, more generally, time and cognitive constraints compel restricting attention to a limited set of inputs and tasks.

An investor who tries to forecast firms' prospects is faced with the arrival of many information signals over time. Psychologists have studied experimentally how subjects learn over time to forecast a variable that is stochastically related to multiple cues (see, e.g., Baker et al. (1993), Busemeyer, Myung, and McDaniel (1993), and Kruschke and Johansen (1999)). A consistent finding in both animal and human studies is that cue competition occurs: The arrival of irrelevant cues causes subjects to use relevant cues less. In financial markets, investors presumably try to economize on attention by filtering away irrelevant signals, but it is not clear whether such findings extend to markets. Therefore, we test whether stock investors are prone to underreact to relevant information about a firm when there is greater arrival of irrelevant signals.

\section{B. Why Distraction Can Affect Security Prices}

A limited attention explanation for an asset pricing pattern must explain why investors who are not paying full attention would participate in markets and affect prices, and why any such effects are not eliminated by the trades of fully rational arbitrageurs. The issue of arbitrage has been addressed by many papers in behavioral finance; if the risk-bearing capacity of fully rational individuals is finite, then their beliefs do not dominate prices in the short run; instead, prices reflect a weighted average of investor beliefs, where the weights depend on the frequencies of different investor types in the population and on their risk tolerance.

In the long run, we might expect wealth on average to flow from less rational traders to more rational traders, which could diminish the influence of imperfectly rational traders on prices. For example, if institutional investors are more sophisticated than individual investors, we might expect invested wealth to largely end up in the hands of institutions. Again, this is a standard issue in the behavioral finance literature, and there are some standard responses: stock prices are noisy so that this wealth-transfer process can be slow, in the long-run new generations of naive traders enter the market, naive individual investors find it hard to identify which mutual funds or institutions will manage their money effectively, institutional managers are also imperfectly rational, and owing either to aging or to psychological biases in learning 
processes, some investors may learn to be less rather than more rational over time. Several recent empirical studies have questioned the rationality of trading by institutional investors (e.g., Coval and Shumway (2005)), and one recent study provides evidence suggesting that, indeed, irrational trading by institutions is a source of post-earnings announcement drift (Frazzini (2006)).

In the specific context of limited attention, owing to cognitive resource constraints, all investors have limited attention, so there is no way for a flow of wealth to fully eliminate its effects (see, e.g., Hirshleifer and Teoh (2005)). Even if some investors allocate resources heavily to the study of a given stock at a given time, and therefore are highly attentive toward that stock, this entails withdrawal of cognitive resources from other activities, so we cannot conclude that wealth will tend to flow toward such an investor.

A different set of arguments against limited attention affecting security pricing are based on investors being able to adjust intelligently to deal with limited attention. For example, one can leverage attention by focusing on more important signals. However, it can be hard to know how important an item is until it is carefully processed.

Alternatively, an investor who is neglecting relevant public information about a stock could withdraw from trading in that stock, so that his beliefs are not reflected in its price. However, the same processing and memory constraints that cause neglect of a signal also make it hard to compensate optimally for the failure to attend to it. For example, an investor whose valuation disagrees with the market price may inattentively fail to reason through why the market price differs from his own valuation. Experimental evidence that the presentation format of decision problems affects choice (e.g., Tversky and Kahneman (1981)) indicates that individuals do not compensate optimally for the limitations in their information processing. Empirically, there are strong indications that investors are very willing to trade even when they do not possess superior valuations (Barber and Odean (2000)). ${ }^{2}$

Other psychological evidence also indicates that individuals do not fully compensate for the fact that they do not possess all relevant information. For example, when presented with one-sided arguments and evidence and asked to judge a legal dispute, experimental subjects are biased in favor of the side they heard (Brenner, Koehler, and Tversky (1996)). As the authors state, "The results indicate that people do not compensate sufficiently for missing information even when it is painfully obvious that the information available to them is incomplete" (p. 59).

Furthermore, we argue that it is reasonable to trade even though one is neglecting some information. Traditional models of information and securities markets such as Grossman and Stiglitz (1976) provide the insight that, owing to liquidity or noise trading, prices aggregate information imperfectly. As a

\footnotetext{
${ }^{2}$ An additional possible source of such neglect is overconfidence, a well-documented psychological bias. An overconfident individual who wrongly thinks that he has already incorporated the most important signals may not perceive the urgency of adjusting for the fact that he is neglecting a relevant public signal.
} 
consequence, these models imply that even an uninformed individual who is trading against others who are better informed should trade based upon his beliefs rather than lapse into passivity. Intuitively, such an investor benefits by supplying liquidity to the market, and taking advantage of any mispricing created by liquidity trades. Analogously, even an investor who neglects a public signal can benefit from contrarian trading (e.g., through limit orders) based upon his beliefs. Such contrarian trading could on average be profitable. ${ }^{3}$

\section{The Data}

We use quarterly earnings announcement data from the CRSP-Compustat merged database and I/B/E/S from 1995 to 2004. To calculate the daily number of quarterly earnings announcements, we look at quarterly earnings announcements available from the CRSP-Compustat merged database. When the announcement date is also available at $\mathrm{I} / \mathrm{B} / \mathrm{E} / \mathrm{S}$ but is different from the Compustat date, we take the earlier date following DellaVigna and Pollet (2009), who report that the earlier of the two dates is almost always the correct announcement date in the post 1994 period in a random sample of checks on the accuracy of the announcement dates. While the accuracy of the announcement date is likely to be higher when it is available from both $\mathrm{I} / \mathrm{B} / \mathrm{E} / \mathrm{S}$ and Compustat, we include Compustat earnings announcements without matching I/B/E/S data when we compute the number of competing announcements because I/B/E/S covers relatively large firms (see, e.g., Hong, Lim, and Stein (2000)). Our sample firms are limited to those that have I/B/E/S coverage; we therefore expect very accurate announcement dates for our sample even though the number of competing announcements can be slightly noisy.

To estimate the forecast error $(F E)$ as a measure of the earnings surprise, we calculate the difference between announced earnings as reported by $\mathrm{I} / \mathrm{B} / \mathrm{E} / \mathrm{S}$ $\left(e_{i q}\right)$ and the consensus earnings forecast $\left(F_{i q}\right)$, defined as the median of the most recent forecasts from individual analysts using the I/B/E/S detail tape. The difference between the announced earnings and the consensus forecast is normalized by the stock price at the end of the corresponding quarter $\left(P_{i q}\right)$ :

$$
F E_{i q}=\frac{e_{i q}-F_{i q}}{P_{i q}}
$$

To exclude stale forecasts when we calculate the consensus forecast, we only include one- or two-quarter-ahead forecasts issued or reviewed in the last 60 calendar days before the earnings announcement. If an analyst made multiple forecasts during that period, we take her most recent forecast. Earnings, forecasts, and stock prices are all split-adjusted. To minimize possible data errors, we delete observations when earnings or forecasts are greater than the stock price, or when the stock price is less than $\$ 1$ before split-adjustment.

\footnotetext{
${ }^{3}$ Kaniel, Saar, and Titman (2008) find that contrarian trading allows U.S. individual investors to earn positive excess returns in the month after their trades.
} 
The cumulative abnormal returns of the announcement and postannouncement windows are defined as the difference between the buy-andhold return of the announcing firm and that of a size and book-to-market (B/M) matching portfolio over the windows $[0,1]$ and $[2,61]$ in trading days relative to the announcement date,

$$
\begin{aligned}
C A R[0,1]_{i q} & =\prod_{k=t}^{t+1}\left(1+R_{i k}\right)-\prod_{k=t}^{t+1}\left(1+R_{p k}\right) \\
C A R[2,61]_{i q} & =\prod_{k=t+2}^{t+61}\left(1+R_{i k}\right)-\prod_{k=t+2}^{t+61}\left(1+R_{p k}\right),
\end{aligned}
$$

where $R_{i k}$ is the return of the firm $i$ and $R_{p k}$ is the return of the matching size-B/M portfolio on day $k$, where $t$ is the announcement date of quarter $q$ 's earnings.

We focus primarily on 60 trading days for the post-announcement window because Bernard and Thomas (1989) report that most of the drift occurs during the first 60 trading days after the announcement (about 3 calendar months). However, to examine how distraction effects dissipate when new information arrives, we also perform some tests with time horizons ranging from 30 to 90 days. Each stock is matched with 1 of 25 size-B/M portfolios at the end of June based on the market capitalization at the end of June and the book equity of the last fiscal year-end in the prior calendar year divided by the market value of equity at the end of December of the prior year. The daily returns of the 25 size-B/M portfolios are from Kenneth French's web site. ${ }^{4}$

\section{Univariate Tests of the Investor Distraction Hypothesis}

We specify the investor distraction hypothesis as containing three parts: (i) the sensitivity of the announcement abnormal return to earnings news decreases with the number of competing announcements; (ii) the abnormal trading volume on the day of the announcement decreases with the number of competing announcements; (iii) the sensitivity of the post-announcement abnormal return to earnings news increases with the number of competing announcements.

The first and the third predictions imply opposite directions for the effect of the number of competing news announcements on the announcement-period sensitivity of the firm's stock return to its earnings surprise, versus the sensitivity of the post-event return. This helps distinguish the investor distraction hypothesis from alternative theories. For example, it might be argued that competing news announcements affect the informativeness of the firm's earnings announcement. However, such an alternative theory predicts the same direction of effect on the announcement period and the post-event sensitivity of returns

\footnotetext{
${ }^{4}$ http://mba.tuck.dartmouth.edu/pages/faculty/ken.french/data_library.html
} 
to the firm's earnings surprise (holding constant the fraction of the total response to the earnings surprise that is delayed). We discuss this issue in more depth at the end of Section IV.A.1.

\section{A. Descriptive Statistics}

Table I Panel A reports the descriptive statistics of the daily number of quarterly earnings announcements. The mean number of announcements a day is 120.8 and the median number is 71 . The percentiles of the number of announcements show that there is wide variation in the number of earnings announcements per day; the 10th percentile number of announcements is 20 and the 90 th percentile is 290 .

In results reported in an Internet Appendix ${ }^{5}$, we find that earnings announcements cluster by day of week and show a highly seasonal pattern. As documented by other studies, the number of announcements is higher on Tuesday, Wednesday, and Thursday, and lowest on Friday (e.g., Damodaran (1989), DellaVigna and Pollet (2009)). When examined by month, the number of announcements shows an approximately 3-month cycle, with the lowest number of announcements in March, June, September, and December. This pattern reflects the fact that about $60 \%$ of the announcements are for fiscal quarters ending in March, June, September, and December and it takes 1-2 months from the end of the fiscal quarter until the earnings announcement date.

Table I Panel B shows the sample characteristics by the decile rank of the number of announcements, $N R A N K$. The decile rank is based on quarterly sorts of earnings announcement observations by the number of announcements on the announcement day. We later employ the firm characteristic variables as controls in regression analyses, so we delete observations for which we lack information on any of the control variables.

The size and B/M ratios are calculated at the end of June of each year based on the market value of equity at the end of June and the book value of equity for the last fiscal year-end in the previous calendar year divided by the market value of equity for December of the previous calendar year. Earnings Persistence is the first-order autocorrelation coefficient of quarterly earnings per share during the past 4 years (split-adjusted; minimum four observations required), institutional ownership $(I O)$ is the percentage of shares owned by institutions at the end of the most recent calendar quarter constructed from the CDA / Spectrum $13 \mathrm{~F}$ database, and Earnings Volatility is the standard deviation during the preceding 4 years of the deviations of quarterly earnings from 1-year-ago earnings (split-adjusted; minimum four observations required). Reporting Lag is the number of days from the quarter-end until the earnings announcement date, \# Analysts is the number of analysts following the firm during the most recent fiscal year, and Share Turnover is defined as the average monthly share trading

\footnotetext{
${ }^{5}$ An Internet Appendix for this article is online in the "Supplements and Data Sets" section at http://www.afajof.org/supplements.asp.
} 


\section{Table I}

\section{Sample Descriptive Statistics}

Using quarterly earnings announcement dates from the CRSP-Compustat merged database and I/B/E/S for the period from January 1995 to December 2004, we calculate the total number of announcements on each day. In each calendar quarter, we sort quarterly earnings announcements during that quarter into deciles by the total number of announcements on the day of the announcement. Panel A reports the distribution of the daily total number of announcements. Panel B reports the average Size, B/M, Earnings Surprise, Earnings Persistence, institutional ownership (IO), Earnings Volatility, Reporting Lag, and the number of analysts following the firm (\# Analysts) by the number-of-announcements deciles (NRANK), after deleting observations with missing information for any of these variables. See Section III.A for variable definitions. Panel C shows standardized regression coefficient estimates where NRANK is the dependent variable other variables in Panel B are independent variables. All variables are standardized to have mean zero and standard deviation of 1 . Standard errors of coefficients are adjusted for heteroskedasticity and clustering by the day of announcement. ${ }^{*},{ }^{* *},{ }^{* * *}$ indicate significance at the $10 \%, 5 \%$, and $1 \%$ level, respectively.

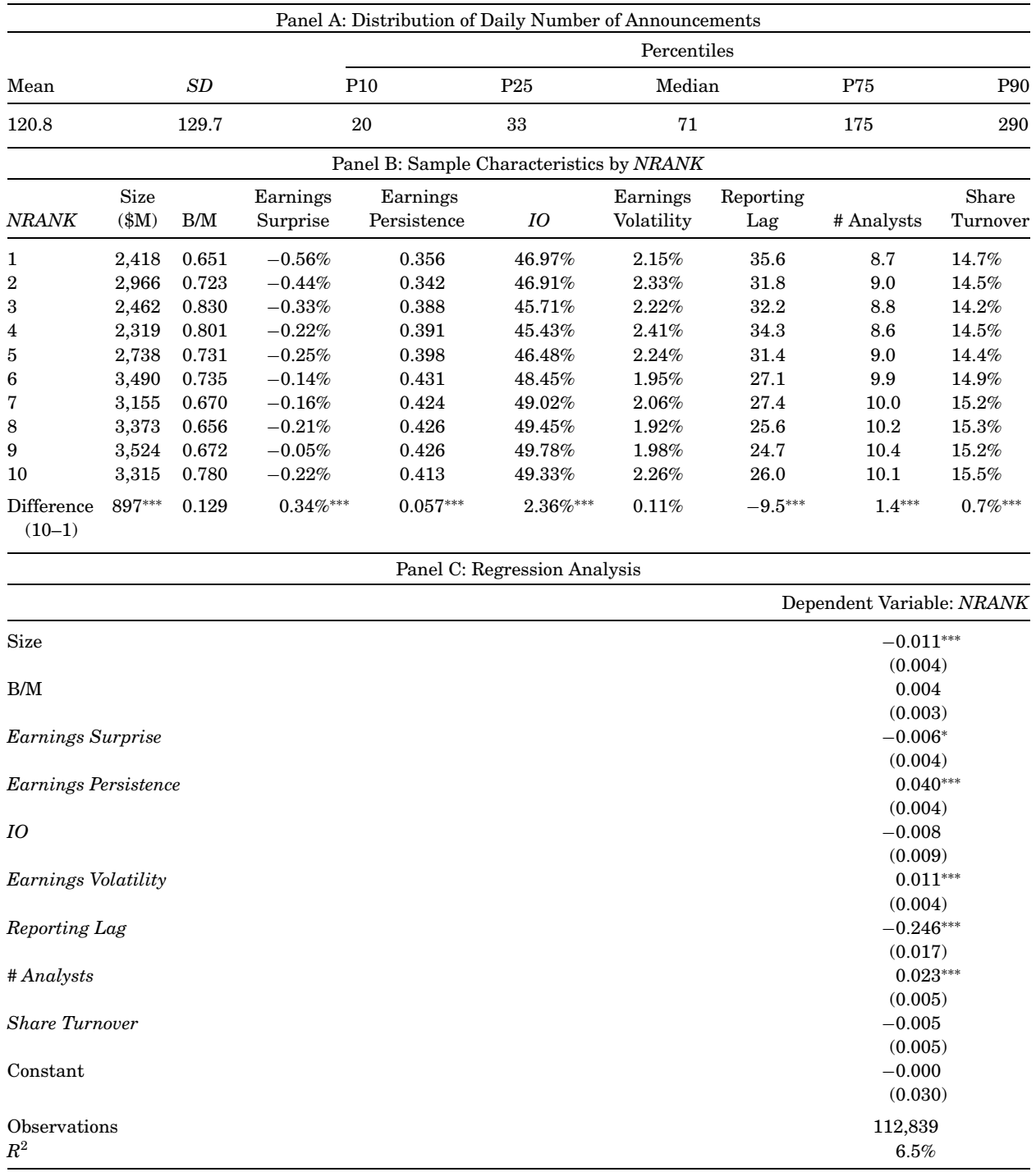


volume divided by the average number of shares outstanding during a 1-year period ending at the end of the corresponding fiscal quarter.

We find that earnings announcements on high-news days $(N R A N K=10)$ are from larger firms with greater institutional ownership and analyst following than those on low-news days $(N R A N K=1)$. High-news-day announcements are associated with less negative earnings surprises, more persistent earnings, smaller reporting lags, and higher share turnover compared to lownews-day announcements. There is no significant difference in B/M ratios or earnings volatility between the two extreme number-of-announcements deciles. However, the characteristics do not vary monotonically across the number of announcement deciles. For example, deciles 3 and 4 have relatively low size and high $\mathrm{B} / \mathrm{M}$ ratios. We also find that the industry compositions are substantially different across NRANK (see Internet Appendix). For instance, 23.67\% of low-news-day announcements and $9.05 \%$ of high-news-day announcements are from Industry 7 (Shops) of the Fama-French 10 industry classification.

In Panel $\mathrm{C}$, we regress the number of announcement deciles (NRANK) on the variables in Panel $\mathrm{B}$ to examine how each variable is related to NRANK after controlling for the effect of other variables. To make comparison easier, we standardize all variables by subtracting the mean and then dividing by its standard deviation. Some of the relations change sign or significance in the multivariate analysis. For example, Size is positively related to NRANK in the univariate analysis in Panel $\mathrm{B}$, but the relation is negative after controlling for other variables. Comparing coefficient estimates, we find that Reporting Lag has the strongest relation to the number-of-announcements deciles.

\section{B. Announcement Date Returns and Post-earnings Announcement Drift}

We first perform univariate analysis to examine the effect of competing news on price reactions to earnings news. In each calendar quarter, we perform a two-way independent sort of quarterly earnings announcement observations in that quarter into $10 \times 10=100$ groups based upon the number of earnings announcements on the day of the earnings announcement and the earnings surprise (forecast error) as defined in equation (1). For each numberof-announcements decile, we calculate the mean announcement period and post-announcement period cumulative abnormal returns for the most positive $(F E 10)$ and the most negative (FE1) earnings surprise deciles, and the difference in announcement and post-announcement cumulative abnormal returns between the two extreme earnings surprise deciles.

The spread in abnormal announcement day returns between earnings surprise deciles 10 and 1 ( $F E 10-F E 1)$ measures the stock price response to earnings news; a larger spread indicates that investors react more strongly to earnings news on the announcement date. The spread in post-announcement abnormal returns between earnings surprise deciles 10 and 1 measures underreaction to earnings news as reflected in subsequent drift. If the market is efficient, there will be no difference between good earnings news and bad earnings news firms in their post-announcement abnormal returns. A positive spread indicates underreaction to earnings news-positive abnormal returns following 


\section{Table II \\ Cumulative Abnormal Returns of Extreme Earnings Surprise Deciles by Number-of-Announcements Deciles}

Using quarterly earnings announcements from January 1995 to December 2004, we calculate the average 2-day announcement cumulative abnormal returns $(C A R[0,1])$ and 60 -day postannouncement cumulative abnormal returns $(C A R[2,61])$ for extreme earnings surprise deciles (FE10: good news, FE1: bad news) by the number-of-announcements deciles (NRANK). Earnings surprise and number-of-Announcements deciles are formed based on quarterly independent double sorts of quarterly earnings announcements by the corresponding forecast error and the number of quarterly earnings announcements on the day of announcement. The $p$-values are calculated using standard errors adjusted for heteroskedasticity and clustering by date. *, **, *** indicate significance at the $10 \%, 5 \%$, and $1 \%$ level, respectively.

\begin{tabular}{|c|c|c|c|c|c|c|}
\hline \multirow[b]{2}{*}{$N R A N K$} & \multicolumn{3}{|c|}{$\begin{array}{l}\text { Average } C A R[0,1] \text { for Earnings } \\
\text { Surprise Deciles } 1 \text { and } 10\end{array}$} & \multicolumn{3}{|c|}{$\begin{array}{l}\text { Average } C A R[2,61] \text { for Earnings } \\
\text { Earnings Surprise Deciles } 1 \text { and } 10\end{array}$} \\
\hline & $F E 1$ & $F E 10$ & $F E 10-F E 1$ & $F E 1$ & $F E 10$ & $F E 10-F E 1$ \\
\hline 1 & $-3.17 \%$ & $3.86 \%$ & $7.02 \% \%^{* * *}$ & $-0.70 \%$ & $1.96 \%$ & $2.66 \% *$ \\
\hline 2 & $-3.37 \%$ & $3.51 \%$ & $6.88 \% \%^{* * *}$ & $-1.57 \%$ & $3.49 \%$ & $5.05 \%$ *** \\
\hline 3 & $-3.18 \%$ & $3.63 \%$ & $6.80 \% \%^{* * *}$ & $-1.56 \%$ & $2.15 \%$ & $3.71 \% * *$ \\
\hline 4 & $-3.51 \%$ & $2.54 \%$ & $6.05 \% * * *$ & $-4.47 \%$ & $3.62 \%$ & $8.09 \% * * *$ \\
\hline 5 & $-3.26 \%$ & $2.28 \%$ & $5.54 \% \%^{* * *}$ & $-2.32 \%$ & $2.58 \%$ & $4.90 \%$ *** \\
\hline 6 & $-2.99 \%$ & $3.27 \%$ & $6.26 \% \%^{* * *}$ & $1.10 \%$ & $3.93 \%$ & $2.83 \%$ \\
\hline 7 & $-3.64 \%$ & $2.78 \%$ & $6.42 \% \%^{* * *}$ & $-2.86 \%$ & $2.88 \%$ & $5.74 \%^{* * *}$ \\
\hline 8 & $-3.51 \%$ & $2.79 \%$ & $6.30 \% \%^{* * *}$ & $-2.61 \%$ & $6.79 \%$ & $9.40 \%$ *** \\
\hline 9 & $-3.65 \%$ & $2.82 \%$ & $6.47 \% \%^{* * *}$ & $-1.21 \%$ & $4.34 \%$ & $5.54 \%^{* * *}$ \\
\hline 10 & $-3.15 \%$ & $2.66 \%$ & $5.81 \%$ *** & $-2.73 \%$ & $4.45 \%$ & $7.18 \% \%^{* * *}$ \\
\hline Difference (10-1) & $0.02 \%$ & $-1.19 \%$ ** & $-1.21 \% *$ & $-2.02 \%$ & $2.49 \%$ & $4.52 \% * *$ \\
\hline
\end{tabular}

good news and negative abnormal returns following bad news. The distraction hypothesis predicts a smaller $C A R[0,1]$ spread (weaker announcement-day reaction) and a larger $C A R[2,61]$ spread (stronger post-announcement drift) for high-news days compared to low-news days.

Table II shows that investors' 2-day announcement reactions to earnings news are less sensitive to earnings news when earnings are announced on highnews days $(N R A N K=10)$ than low-news days $(N R A N K=1)$. For the lowest number-of-announcements decile (low-news days), the mean spread in 2-day cumulative announcement returns $(C A R[0,1])$ between good earnings news firms $(F E 10)$ and bad earnings news firms $(F E 1)$ is $7.02 \%$, whereas for the highest number-of-announcements decile, the mean spread is $5.81 \% .^{6}$ This indicates that the price reactions to earnings news are stronger when earnings are announced on low-news days than on high-news days.

Greater competing news is also associated with stronger post-earnings announcement drift. The spread in mean 60-day post-announcement abnormal

\footnotetext{
${ }^{6}$ Although the effect is fairly close to monotonic, it is evident from Table II that these differences are smaller when the test is performed with extreme quintiles rather than deciles of NRANK. As is common in studies on anomalies, including those on drift, the effect is strongest in the extreme deciles.
} 
returns $(C A R[2,61])$ between good and bad earnings news deciles indicates greater underreaction to earnings news on high-news days than on low-news days. For high-news days, the post-announcement abnormal return spread between extreme earnings surprise deciles is substantial $(7.18 \%)$ and highly significant $(p<0.001)$, whereas the low-news days spread is smaller $(2.66 \%)$ and marginally significant at the $10 \%$ level. However, the spread in the post-announcement abnormal returns is not monotonic across the number-ofannouncements deciles $(N R A N K)$. The source of this non-monotonicity may be differences in size and $\mathrm{B} / \mathrm{M}$ across the number of announcement deciles (see Table I, Panel B). Therefore, we conduct multivariate regression analysis in Section IV.A to control for the effect of firm characteristics such as size, bookto-market, and calendar effects (day of week, month, or year) on the relation between announcement or post-announcement abnormal returns and earnings news.

The last row of Table II reports the difference between high- and low-news days. The difference between high- and low-news days in interdecile spreads (FE10-FE1) of $C A R[0,1]$ is $-1.21 \%$ and the difference of interdecile spreads of $C A R[2,61]$ is $4.52 \%$. To verify that these differences are statistically meaningful, we estimate the following regression model using all announcements in the top and bottom of the earnings surprise deciles and top and bottom of the number of announcements:

$$
C A R=a_{0}+a_{1}(F E 10)+a_{2}(N R A N K 10)+a_{3}(F E 10)(N R A N K 10)+\varepsilon,
$$

where $F E 10$ is an indicator variable that is equal to one for the top decile of earnings surprise and zero for the bottom decile of earnings surprise, NRANK10 is an indicator variable that is equal to one for the top decile of the number of announcements (high-news days) and zero for the bottom decile (lownews days), $C A R=C A R[0,1]$ for the announcement date abnormal returns, and $C A R=C A R[2,61]$ for the post-announcement cumulative abnormal returns. Thus, the regression coefficient $a_{3}$ tests whether $C A R$ spreads between good and bad earnings news firms are significantly different on low-news days versus high-news days.

The regression estimate of $a_{3}$ indicates that the $-1.21 \%$ difference between high- and low-news days in the return spreads between good and bad earnings news firms for $C A R[0,1]$ is significant at the $10 \%$ level and the $4.52 \%$ difference for $C A R[2,61]$ is significant at the $5 \%$ level using standard errors adjusted for heteroskedasticity and clustering by date.

Figures 1 and 2 provide graphical evidence that announcement date market reactions are less sensitive to the earnings surprise, and that subsequent drifts are more sensitive to the earnings surprise, when earnings are announced on high-news days than low-news days. In Figure 1, the abnormal announcement return $(C A R[0,1])$ is plotted against earnings surprise deciles separately for high-news days (Decile 10) and low-news days (Decile 1). The lower sensitivity of the market reaction to earnings news on high-news days is reflected by a flatter slope in the graph. 


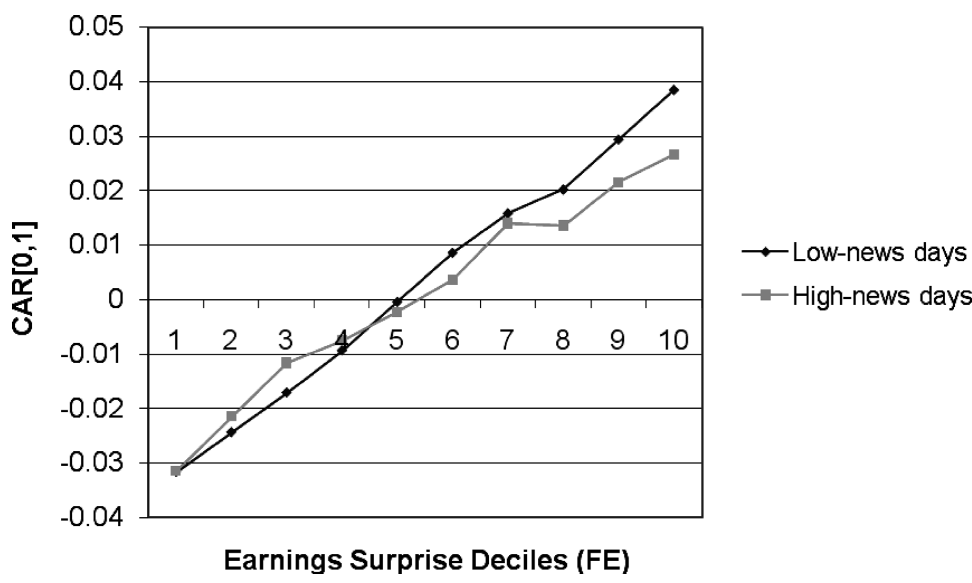

Figure 1. Market reactions to earnings news: $\boldsymbol{C A R}[0,1]$. Figure 1 shows the average 2day announcement cumulative abnormal returns $(C A R[0,1])$ of quarterly earnings announcements against earnings surprise deciles ( $F E=1$ : bad news, 10: good news) for announcements on highnews days (number-of-announcements Decile 10) and low-news days (number-of-announcements Decile 1). Earnings surprise and the number-of-announcements deciles are formed based on a quarterly independent double sort of quarterly earnings announcements by the corresponding forecast error and the number of quarterly earnings announcements on the day of the announcement.

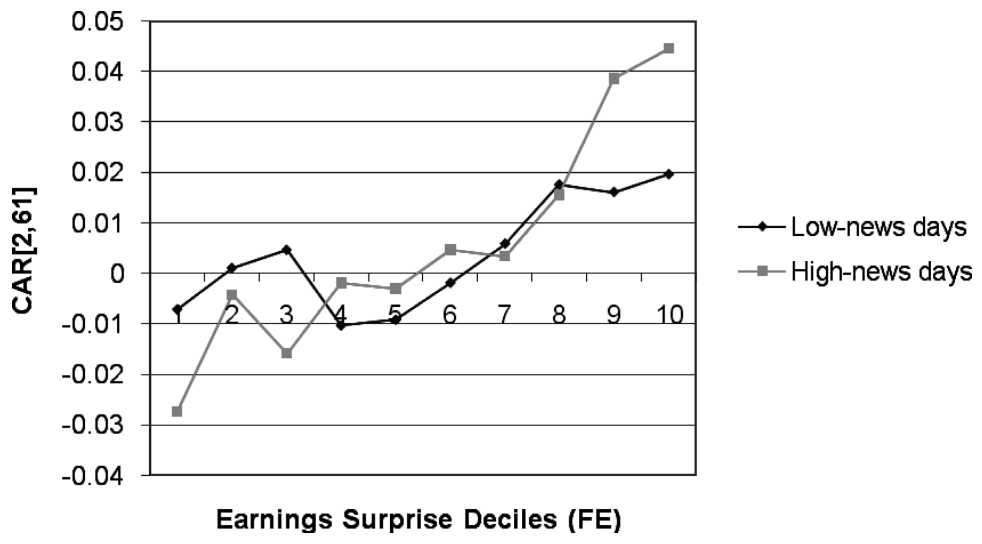

Figure 2. Post-earnings announcement drift: $C A R[2,61]$. Figure 2 shows the average 60 -day post-announcement cumulative abnormal returns $(C A R[2,61])$ of quarterly earnings announcements against earnings surprise deciles $(F E=1$ : bad news, 10: good news) for announcements on high-news days (number-of-announcements decile 10) and low-news days (number-ofannouncements Decile 1). Earnings surprise and the number-of-announcements deciles are formed based on a quarterly independent double sort of quarterly earnings announcements by the corresponding forecast error and the number of quarterly earnings announcements on the day of the announcement. 
Figure 2 shows mean post-announcement abnormal returns $(C A R[2,61])$ as a function of earnings surprise deciles. The greater slope of the high-news day graph shows that post-announcement abnormal returns are more sensitive to earnings news on high-news days than on low-news days. Figures 1 and 2 and the univariate results in Table II suggest that investors react more sluggishly to earnings news when they are distracted by competing announcements.

\section{Multivariate Tests}

To control for other possible determinants of investor responses to earnings news, we perform multivariate tests. Section A describes how competing news affects the sensitivity of returns to a firm's earnings news. Section B describes how competing news affects the trading volume response to a firm's earnings news.

\section{A. Distraction and the Return Response to Earnings News}

\section{A.1. Full Sample Tests}

In order to control for possible sources of variation in the relation between announcement date returns and earnings news, and between postannouncement drift and earnings news, we run regressions of 2-day announcement abnormal returns $(C A R[0,1])$ or 60 -day post-announcement abnormal returns $(C A R[2,61])$ on the earnings surprise decile rank $(F E)$, the number-ofannouncements decile rank $(N R A N K)$, the interaction term $F E \times N R A N K$, and control variables, also interacted with $F E$ :

$$
\begin{aligned}
C A R= & a_{0}+a_{1} F E+a_{2} N R A N K+a_{3}(F E \times N R A N K) \\
& +\sum_{i=1}^{n} c_{i} X_{i}+\sum_{i=1}^{n} b_{i}\left(F E \times X_{i}\right)+\varepsilon
\end{aligned}
$$

The investor distraction hypothesis posits that the announcement return is less sensitive and the post-announcement return is more sensitive to earnings news on high-news days. Thus, we expect $a_{3}<0$ when we use $C A R[0,1]$ as the dependent variable and $a_{3}>0$ when we use $C A R[2,61]$ as the dependent variable.

Because the relation between announcement-day abnormal returns and earnings surprise is highly nonlinear (e.g., Kothari (2001)), with small negative surprises having big effects, we use the decile rank of forecast error as opposed to the forecast error itself following past literature. This reduces the influence of outliers, and the relation between $C A R[0,1]$ and the earnings surprise deciles is almost linear (see Figure 1).

Previous research shows that investor reactions to earnings news vary with firm size, book-to-market, number of analysts following, reporting lag, institutional ownership, earnings persistence, and day of the week (e.g., Chambers and Penman (1984), Bernard and Thomas (1989), DellaVigna and Pollet (2009)). 


\section{Table III}

\section{Market Reactions to Earnings News: Regression Analysis}

Table III reports the multivariate tests of the effects of the number of announcements on the relation between announcement or post-announcement returns and earnings surprises. The dependent variable is indicated under each column heading. $F E$ is the earnings surprise decile $(F E=1$ : lowest, 10: highest) and NRANK is the number-of-announcements decile, based on quarterly independent sorts by forecast error and the number of announcements on the day of announcement. Regressions (5) and (6) include observations in extreme earnings surprise deciles only ( $F E=1$ or 10$)$; $F E 10$ is an indicator variable for the top earnings deciles $(F E=10)$. Control variables include size and book-tomarket deciles, log (1 + \# Analysts), Reporting Lag, Reporting Lag squared and cubed, institutional ownership (IO), Earnings Volatility, Earnings Persistence, Share Turnover, and indicator variables for year, month, day of week, and Fama-French 10 industry classification. See Section III.A for variable definitions. All control variables are interacted with $F E$ (FE10 for Regressions 5 and 6 ). Standard errors adjusted for heteroskedasticity and clustering by the day of announcement are in parentheses. ${ }^{*},{ }^{* *}, * *$ indicate significance at the $10 \%, 5 \%$, and $1 \%$ level, respectively.

\begin{tabular}{|c|c|c|c|c|c|c|}
\hline & $\begin{array}{c}(1) \\
\text { CAR }[0,1]\end{array}$ & $\begin{array}{c}(2) \\
\text { CAR }[0,1]\end{array}$ & $\begin{array}{c}(3) \\
\operatorname{CAR}[2,61]\end{array}$ & $\begin{array}{c}(4) \\
\text { CAR[2,61] }\end{array}$ & $\begin{array}{c}(5) \\
\text { CAR }[0,1]\end{array}$ & $\begin{array}{c}(6) \\
\text { CAR }[2,61]\end{array}$ \\
\hline$F E$ & $\begin{array}{l}0.722^{* * *} \\
(0.022)\end{array}$ & $\begin{array}{l}1.028^{* * *} \\
(0.098)\end{array}$ & $\begin{array}{l}0.372^{* * *} \\
(0.074)\end{array}$ & $\begin{array}{l}0.979^{* * *} \\
(0.322)\end{array}$ & & \\
\hline$F E \times N R A N K$ & $\begin{array}{c}-0.008^{* *} \\
(0.004)\end{array}$ & $\begin{array}{c}-0.015^{* * *} \\
(0.005)\end{array}$ & $\begin{array}{l}0.034^{* * *} \\
(0.012)\end{array}$ & $\begin{array}{l}0.049^{* *} \\
(0.019)\end{array}$ & & \\
\hline FE10 & & & & & $\begin{array}{l}10.730^{* * *} \\
(1.463)\end{array}$ & $\begin{array}{c}9.869^{* *} \\
(4.709)\end{array}$ \\
\hline$F E 10 \times N R A N K$ & & & & & $\begin{array}{c}-0.178^{* *} \\
(0.073)\end{array}$ & $\begin{array}{c}0.511^{* *} \\
(0.252)\end{array}$ \\
\hline $\begin{array}{l}\text { Controls, } \\
\text { interacted } \\
\text { with } F E\end{array}$ & & $\mathrm{X}$ & & $\mathrm{X}$ & $\mathrm{X}$ & $\mathrm{X}$ \\
\hline Constant & $\begin{array}{c}-3.817^{\text {**** }} \\
(0.134)\end{array}$ & $\begin{array}{c}-5.386^{* * *} \\
(0.577)\end{array}$ & $\begin{array}{c}-2.092^{* * *} \\
(0.462)\end{array}$ & $\begin{array}{c}-7.429^{* * *} \\
(1.959)\end{array}$ & $\begin{array}{c}-3.479^{* * *} \\
(1.065)\end{array}$ & $\begin{array}{c}-7.695^{* *} \\
(3.542)\end{array}$ \\
\hline Observations & 112,839 & 112,839 & 112,839 & 112,839 & 22,203 & 22,203 \\
\hline$R^{2}$ & $5.1 \%$ & $6.2 \%$ & $0.3 \%$ & $1.1 \%$ & $9.9 \%$ & $3.0 \%$ \\
\hline
\end{tabular}

Thus, we include as control variables size and B/M deciles, the number of analysts following the firm $(\log (1+\#$ Analysts $))$, reporting lag, institutional ownership, earnings persistence, earnings volatility, share turnover, day of week/month/year dummies, and industry dummies using Fama-French 10 industry classification. Because NRANK is highly correlated with reporting lag, we also include reporting lag squared and cubed to control for possible nonlinear effects. While our controls may not perfectly control for the effect of reporting lag, we find reporting lags have a negative effect on both immediate and delayed responses. Thus, imperfect control for reporting lag is unlikely to explain the opposite effects of NRANK on immediate and delayed responses.

The regression results are reported in Table III. Standard errors of regression coefficient estimates are adjusted for heteroskedasticity and clustering by the day of announcement. For the announcement return $(C A R[0,1])$, the coefficient on the interaction term $(F E \times N R A N K)$ is negative $(-0.008$ 
without controls, -0.015 with controls) and significant at the $1 \%$ level (Regressions 1 and 2). The coefficient estimates on $F E$ and $F E \times N R A N K$ in Regression 2 imply that the market reactions are significantly less sensitive to earnings news by $13.3 \%$ on high-news days $(N R A N K=10)$ compared to lownews days $(N R A N K=1)$. (The sensitivity is $1.028-(0.015 \times 10)=0.878$ for $N R A N K=10$ and $1.028-(0.015 \times 1)=1.013$ for $N R A N K=1$. $)$ This is comparable to the $12 \%$ to $20 \%$ reduction for Friday announcements documented in DellaVigna and Pollet (2009).

For post-announcement abnormal returns $(C A R[2,61])$, the coefficient on the interaction between earnings surprise decile rank and the number of announcements rank $(F E \times N R A N K)$ is positive ( 0.034 without controls, 0.049 with controls) and significant at the $1 \%$ level (Regressions 3 and 4). DellaVigna and Pollet (2009) report that the post-earnings announcement drift is $69.1 \%$ larger for Friday announcements compared to other weekday announcements in the regression without controls. Our estimates indicate $75.4 \%$ larger drifts for high-news day announcements compared to low-news day announcements in the regression without controls (Regression 3), and 42.9\% larger drifts in the regression with controls (Regression 4).

Based on the coefficients in Table III and the standard deviations of different variables, we compare the effect of a one-standard deviation increase in test or control variables (apart from dummy variables) on return sensitivities to earnings news (see Internet Appendix). The effect of NRANK in both regressions is comparable to that of firm size and greater than that of the number of analysts. We find that NRANK is the most important determinant of the relation between post-announcement abnormal returns and earnings surprise. The coefficients on the interaction terms with $F E$ indicate that a one-standard deviation change in NRANK has a larger absolute effect on the sensitivity of post-announcement abnormal returns to earnings news than the effects of size, $\mathrm{B} / \mathrm{M}$, analyst following, earnings persistence, institutional ownership, earnings volatility, reporting lag (also squared and cubed), or turnover. For the sensitivity of 2-day announcement returns to earnings surprise, institutional ownership (IO) has the largest absolute effect, but NRANK has a similar order of magnitude and has a stronger effect than analyst following, earnings volatility, and earnings persistence.

The results are similar when we use extreme earnings surprise deciles only in Regressions 5 and 6 . The coefficient estimate on $F E \times N R A N K$ is -0.178 for the announcement return (Regression 5 ) and 0.511 for the post-announcement return (Regression 6). The regression estimates indicate that the quantitative nature of the results using extreme earnings surprise deciles are very close to what we obtain using the entire sample. For example, the reduction in the sensitivity of announcement-day abnormal returns to earnings news for highnews day announcements compared to low-news day announcements is $15.2 \%$ using extreme earnings surprise deciles, and $13.3 \%$ using all earnings surprise deciles.

Thus, consistent with the distraction hypothesis, distracting news has opposite effects on the sensitivity of the announcement period reaction to a firm's 
earnings surprise versus the sensitivity of the post-announcement reaction to its earnings surprise. These opposite effects raise a hurdle to alternative explanations such as one based upon the informativeness of earnings announcements; if a variable affects the magnitude of the total reaction, we would often expect effects in the same direction.

One way to assess how common opposing effects are is to examine the effects of our controls on the immediate versus post-announcement reactions. When we do so, we see that 5 of the 43 variables have opposite effects on immediate reaction and drift, namely, analyst following (which seems to subsume size), turnover (which may also be a measure of attention), and the 2002-2004 dummies (a period with weaker drift). ${ }^{7}$ These variables are all plausible proxies (or inverse proxies) for the degree of underreaction. We expect a variable that affects the degree of underreaction to influence the announcement and postannouncement reactions in opposite directions; the less information that is impounded immediately, the more that will be impounded with delay. On the other hand, three control variables have similar effects on the immediate and postannouncement reactions: firm size (negative), earnings persistence (positive), and the Industry 8 (healthcare, medical equipment, and drugs) dummy (negative). These variables could be associated with the informativeness of earnings news. For instance, earnings news is likely to have a bigger impact on stock price when earnings are highly persistent, implying stronger immediate response and drift.

These findings suggest that a few variables affect the degree of underreaction. Of course, we explicitly control for this using a number of variables. However, our use of controls does not rule out the possibility that some omitted underreaction proxy could explain our results. The good news is that these findings tend to confirm the idea that a variable that affects the degree of underreaction will tend to have opposite effects on immediate reaction versus drift. This is a premise of our tests. In addition, Table III shows that the effect of competing announcements becomes larger after adding control variables, which is encouraging.

\section{A.2. Speed of Correction}

If distraction causes investors to underreact more to earnings news, eventually investors will correct their assessments and the stock will earn abnormal returns. Such correction will tend to create a differential in the post-earnings announcement of high- versus low-news firms. However, such correction does not necessarily start the day of the earnings announcement. We expect the average underreaction to correct gradually as new information arrives. Under the

\footnotetext{
${ }^{7}$ The post-earnings announcement drift anomaly was documented in 1989, and there are some signs that it has somewhat weakened in recent years. In general, there is an incentive for rational arbitrageurs (perhaps hedge funds) to exploit market inefficiencies, which can cause patterns of return predictability to disappear. On the other hand, limits to arbitrage such as transactions costs can cause a degree of market inefficiency to persist. Even in recent years, post-earnings announcement drift remains a strong and significant effect (Hirshleifer et al. (2008)).
} 
limited attention theory, after initial inattention to an earnings surprise owing to competing signals, the news is slowly incorporated into the stock price; much of this underreaction should be corrected by the time of the next one or two earnings announcements.

We therefore test when the differential in post-earnings announcement drift begins, and how long it persists. To do so, we examine post-earnings announcement drift over different horizons (Panel A of Table IV). The number of competing announcements does not have a significant effect on the drift until 45 trading days after the announcement; $F E \times N R A N K$ is insignificant in the regression of $C A R[2,30]$ (Regression 1). Differential drifts become significant around 45 days after the announcement $(C A R[2,45])$, and plateau by 60 days after the announcement. The difference in drift between high-distraction and low-distraction days declines over longer horizons, and becomes small and insignificant by 90 days after the earnings announcement. Apart from the first 30-day time period, the cumulative distraction effect (the coefficient on $F E \times N R A N K$ ) as a percentage of the drift (the coefficient on $F E$ ) is monotonically decreasing over time as we expand the horizon in columns (2) to (5) from 45 days to 90 days. This is consistent with the hypothesis that investor inattention is the source of the distraction effect, which tends to be corrected by the subsequent arrival of information.

\section{A.3. Robustness Checks}

We consider several robustness checks on our findings in an attempt to rule out alternative interpretations. First, errors in announcement dates may potentially create a bias in returns. The estimated sensitivity of the announcementday abnormal return to earnings news can be weaker if there are more errors in our announcement dates in the top number-of-announcements decile (highnews days). Thus, we check the accuracy of our announcement dates with the newswire announcement dates of DellaVigna and Pollet (2009). ${ }^{8}$ DellaVigna and Pollet (2009) hand-collect 2,766 randomly selected earnings announcements from 1984 to 2003 using Lexis-Nexis and the PR newswires. We are able to match 159 low-news day announcements $(N R A N K=1)$ and 59 highnews day announcements, and find three dates that differ from the newswire announcement dates in each case. The error rate is indeed greater in the highnews days than low-news days; however, the sample is too small for the difference in error rates to be statistically significant.

To address the possible effect of errors in announcement dates on return sensitivities, we compute announcement and post-announcement abnormal returns using different windows. We find that the results are quite similar when we start the announcement window on day -1 instead of day 0 (see Internet Appendix) and the post-announcement window on day 3 instead of day 2

\footnotetext{
${ }^{8}$ We thank Stefano DellaVigna for suggesting this robustness check, and Stefano DellaVigna and Joshua Pollet for providing the data.
} 


\section{Table IV}

\section{Market Reactions to Earnings News: Additional Analyses}

Table IV reports additional multivariate tests of the effects of the number of announcements on the relation between returns and earnings surprises. $F E$ is the earnings surprise decile $(F E=1$ : lowest, 10: highest) and NRANK is the number-of-announcements decile, based on quarterly independent sorts by forecast errors and the number of announcements on the day of announcement. Panel A reports the post-earnings announcement drift over 30-, 45-, 61-, 75-, and 90-day horizons, and also over days [3, 61]. In Panel B, Regressions (1) and (2) use beta-adjusted abnormal returns as dependent variables. Regressions (3) and (4) use the subset of firms for which at least $20 \%$ of their extreme-news-day announcements (defined as $N R A N K=1,2,9,10$ ) occur on high-news days $(N R A N K=9,10)$, and at least $20 \%$ occur on low-news days $(N R A N K=1,2)$. Regression (5) shows the cumulative abnormal returns from the announcement day until day 61. Control variables include size and book-to-market deciles, log (1 + \# Analysts), Reporting Lag, Reporting Lag squared and cubed, institutional ownership (IO), Earnings Volatility, Earnings Persistence, Share Turnover, and indicator variables for year, month, day of week, and Fama-French 10 industry classification. See Section III.A for variable definitions. All control variables are interacted with $F E$. Standard errors adjusted for heteroskedasticity and clustering by the day of announcement are in parentheses. ${ }^{*},{ }^{* *},{ }^{* *}$ indicate significance at the $10 \%, 5 \%$, and $1 \%$ level, respectively.

Panel A: Post-Earnings Announcement Drift over Different Horizons

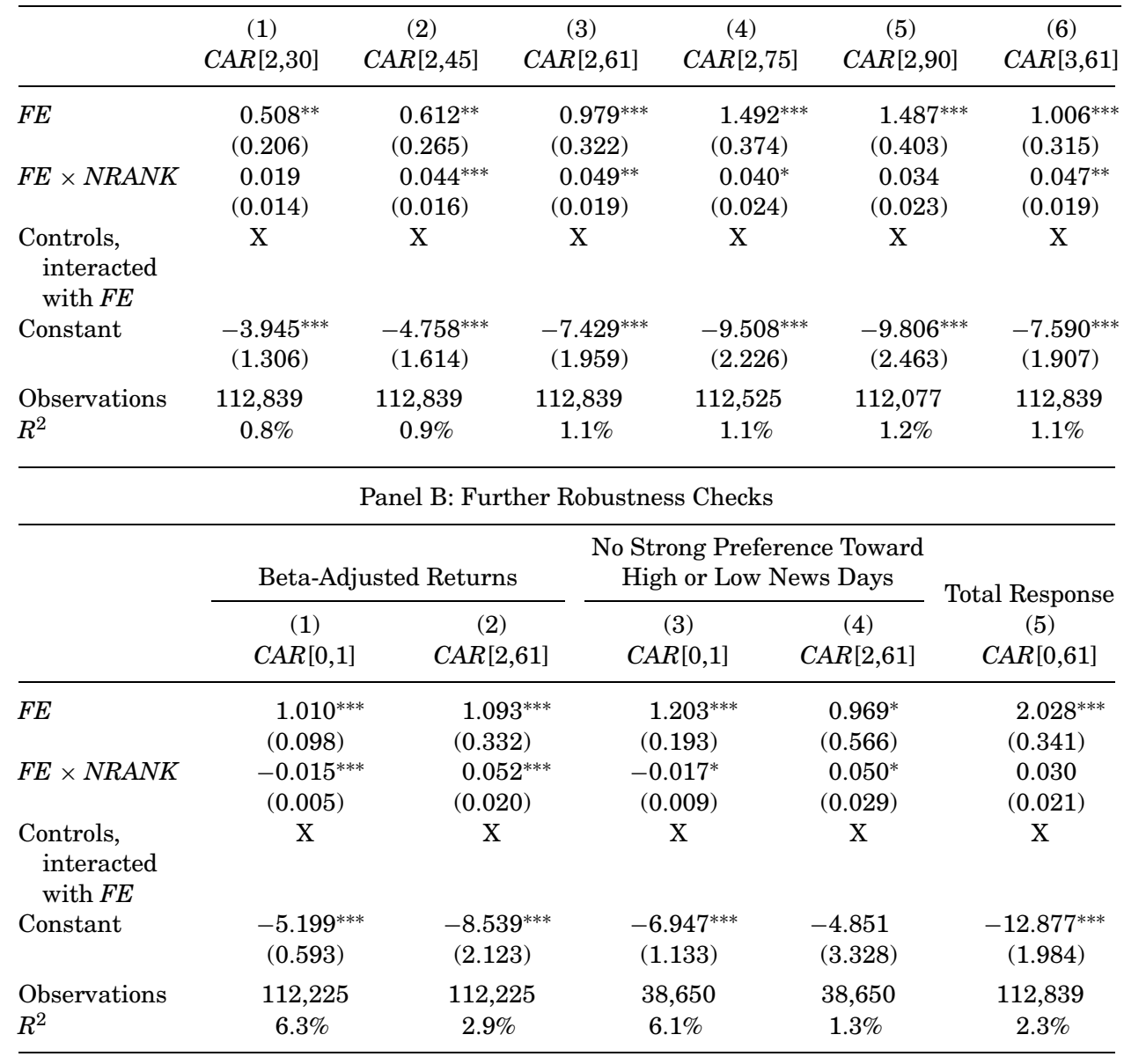




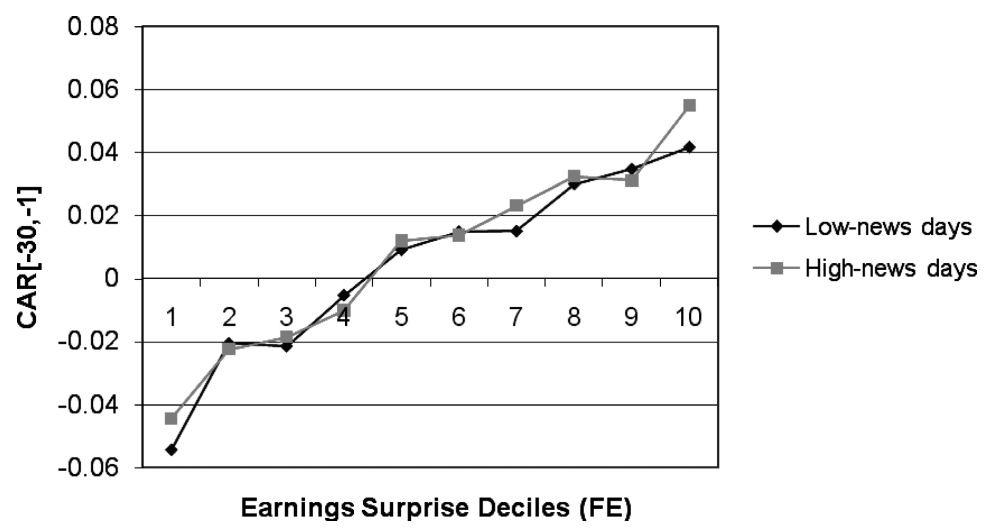

Figure 3. Preannouncement abnormal returns: $\boldsymbol{C A R}[-\mathbf{3 0}, \mathbf{- 1}]$. Figure 3 shows 30 -day preannouncement cumulative abnormal returns $(C A R[-30,-1])$ of quarterly earnings announcements against earnings surprise deciles $(F E=1$ : bad news, 10: good news) for announcements on highnews days (number-of-announcements Decile 10) and low-news days (number-of-announcements Decile 1). Earnings surprise and the number-of-announcements deciles are formed based on a quarterly independent double sort of quarterly earnings announcements by the corresponding forecast error and the number of quarterly earnings announcements on the day of the announcement.

(Regression 6, Table IV Panel A). We therefore conclude that errors in announcement dates are not likely to affect the results.

It is also possible that high-news days are associated with weaker reactions on the announcement date because there is more leakage of earnings news before the announcement. To address this possibility, we examine 30-day abnormal returns before the announcement. Figure 3 shows that, in this preannouncement period, the relation between announcement abnormal returns and earnings news does not significantly differ between high- and low-news days. Also, regression analysis reported in the Internet Appendix confirms that the relation between preannouncement return and earnings surprise decile is not significantly different across NRANK. Thus, there is no indication of any difference in information leakage in relation to $N R A N K$.

Next, certain types of firms may announce on high-news days while other types announce on low-news days, with the difference in unobservable firm characteristics between high- and low-news days driving our results. To address this concern, we restrict the sample to firms that do not show strong preferences toward high- or low-news days in Regressions 3 and 4 of Panel B. For each firm, we compute the number of announcements on high $(N R A N K=9$ and 10) and low (NRANK =1 and 2) news days, and calculate what percentage of these extreme-news-day announcements falls on high- or low-news days. The sample is restricted to firms that have at least $20 \%$ of extreme-news-day announcements on both sides. Using the restricted sample, the coefficients on the interaction term $(F E \times N R A N K)$ are similar in magnitude to those using the full sample, and statistically significant at the $10 \%$ level.

It could also be argued that the number of distracting events affects the informativeness of the firm's earnings about fundamental value. We do not see 
any clear reason why the number of competing announcements should affect the informativeness of the given firm's earnings surprise or the sensitivity of its stock price to its own earnings surprise, nor do we have any presumption as to which way such an effect would go. However, if a given firm's earnings were more informative at times when there are few competing announcements, we would expect both the immediate and total price response to the firm's earnings announcement to be larger at such times. To evaluate this alternative hypothesis, we test directly whether low-news days are associated with a greater total sensitivity of stock prices to earnings news. In Regression 5 in Table IV Panel B, the sensitivity of abnormal returns over days [0,61] to earnings news is used to measure the total effect of earnings news on stock prices. It differs little across the number of announcement deciles.

We also check if the results are sensitive to the way abnormal returns are measured. We find that the results are quite similar when we use abnormal returns based on the capital asset pricing model (CAPM; Regressions 1 and 2, Table IV Panel B). Following DellaVigna and Pollet (2009), we measure the beta of a firm from the regression of daily return on market return over days $[-300,-46]$ before announcement and the abnormal return is computed as the cumulative return of the firm minus the cumulative return of the market multiplied by the beta estimate. The point estimates and standard errors on the interaction term $F E \times N R A N K$ are quite similar whether we use beta-adjusted abnormal returns or characteristic-matched abnormal returns. The $R^{2}$ of the $C A R[2,61]$ regression using beta-adjusted abnormal returns is greater than that using characteristics-adjusted abnormal returns (Table III, Column 4), which may reflect the predictive power of size and $\mathrm{B} / \mathrm{M}$ ratios on beta-adjusted abnormal returns.

Finally, because the number of announcements is highly seasonal, we control for calendar effects by including month, year, and day of week indicator variables in the regressions. To further guard against the possibility that our results are driven by calender effects on the sensitivity of market reactions to earnings news, we examine whether the number of announcements significantly affects market reactions after controlling for the effect of last year's number of announcements in Table V ("Placebo Regressions"). Specifically, LNRANK1(placebo) is the decile rank based on the number of announcements on the closest calendar day with the same weekday the year before. LNRANK2(placebo) is the decile rank based on the number of announcements on the same day of the week and the same week of the month of the previous year (e.g., third Wednesday of November). Table V shows that a greater number of announcements on the corresponding date in the previous year (LNRANK1 or $L N R A N K 2$ ) is associated with weaker immediate reactions and stronger postannouncement drift when we do not include the actual number of announcements this year (NRANK); however, they become insignificant when we include NRANK. These results suggest that our results could be partly driven by seasonality as the previous year's number of announcements has strong predictive power on the relation between earnings news and abnormal returns. However, the fact that NRANK is significant and LNRANK1/LNRANK2 is insignificant 


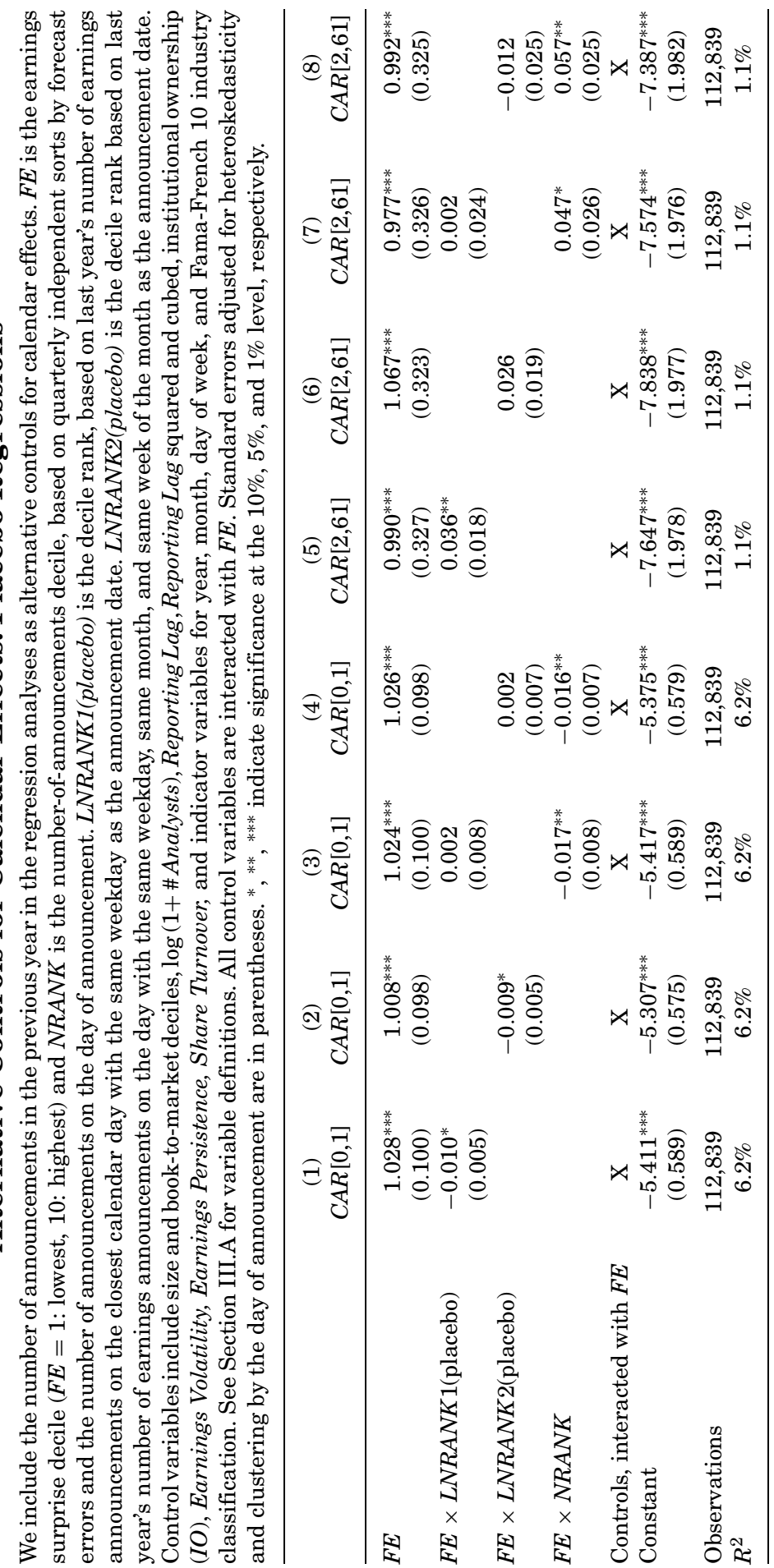


when both are included in the regression suggests that seasonality does not fully explain our findings.

\section{B. Distraction and the Volume Response to Earnings News}

The extent to which investors react to earnings news can also be measured by trading volume in response to the earnings announcement. The investor distraction hypothesis holds that competing announcements will mute the trading volume response to earnings news.

We define abnormal volume on day $j$ relative to the announcement date $t$ as a normalized difference between the log dollar volume on day $j$ and the average log dollar volume over days $[-41,-11]$ of the announcement:

$$
\operatorname{VOL}[j]=\log \left(\text { DollarVol }_{t+j}+1\right)-\frac{1}{30} \sum_{k=t-41}^{t-11} \log \left(\operatorname{DollarVol}_{k}+1\right) \text {. }
$$

We perform regression analysis of the abnormal trading volume over the 2day window around the announcement $(\operatorname{VOL}[0,1])$. The 2-day abnormal trading volume is defined as the average of abnormal trading volumes on the announcement date (VOL[0]) and on the following day (VOL[1]).

Because both extreme positive and negative earnings surprises are likely to generate large trading volume, we regress the 2 -day abnormal trading volume on the decile rank of absolute earnings surprises $(A F E)$, the number-ofannouncements decile rank $(N R A N K)$, and other control variables. In addition to control variables employed in the previous section, we also include the market's abnormal trading volume during the same period so that we are not capturing the market-wide variation in trading volumes. Market abnormal trading volume on a given day is defined as the average abnormal volume of all CRSP firms on that day where the abnormal volume of each firm is calculated in a manner similar to (5).

Table VI shows that the coefficient on NRANK is negative and significant at the $1 \%$ level in all regression models, indicating that abnormal trading volume is lower when earnings are announced on high-news days compared to low-news days, after controlling for the effect of earnings news, market trading volume, firm characteristics, and calendar and industry effects. To control for a possible nonlinear effect of earnings surprise on trading volume, we also use indicator variables for each earnings surprise decile instead of the absolute earnings surprise decile rank (Regressions 3 and 4) and find similar results. Overall, the results show that investor reaction to earnings news as measured by abnormal trading volume is weaker when earnings are announced on high-news days.

\section{Portfolio Trading Strategies}

Another common way of testing for investor biases and for the economic magnitude of their effects on market prices is to measure the abnormal return performance that can be achieved from trading strategies that use variables 


\section{Table VI}

\section{Trading Volume Response to Earnings News}

We perform multivariate analysis of the effect of competing announcements on trading volume response to earnings news. Abnormal trading volume on a given day is defined as the log dollar trading volume on that day normalized by the average log dollar trading volume over days [-41, -11] of the announcement, and the dependent variable $V O L[0,1]$ is the average abnormal trading volume over days $[0,1]$ of the announcement. $A F E$ is the absolute earnings surprise deciles and $N R A N K$ is the number-of-announcements deciles based on quarterly independent sorts by absolute forecast errors and the number of announcements on the day of announcement. Regressions (3) and (4) use indicator variables for each earnings surprise decile. Control variables include size and book-to-market deciles, log (1 + \# Analysts), Reporting Lag, Reporting Lag squared and cubed, institutional ownership (IO), Earnings Volatility, Earnings Persistence, Share Turnover, and indicator variables for year, month, day of week, and Fama-French 10 industry classification. See Section III.A for variable definitions. In addition, we add market abnormal trading volume over days $[0,1]$ of the announcement as an additional control variable, where market abnormal trading volume is defined as the average abnormal volume of all CRSP firms. Standard errors adjusted for heteroskedasticity and clustering by the day of announcement are in parentheses. *, **, *** indicate significance at the $10 \%, 5 \%$, and $1 \%$ level, respectively.

\begin{tabular}{lcccc}
\hline & $(1)$ & $(2)$ & $(3)$ & $(4)$ \\
& $V O L[0,1]$ & $V O L[0,1]$ & $V O L[0,1]$ & $V O L[0,1]$ \\
\hline NRANK & $-0.020^{* * *}$ & $-0.026^{* * *}$ & $-0.022^{* * *}$ & $-0.025^{* * *}$ \\
& $(0.002)$ & $(0.002)$ & $(0.002)$ & $(0.002)$ \\
$A F E$ & $0.019^{* * *}$ & $0.020^{* * *}$ & & \\
& $(0.001)$ & $(0.001)$ & & $\mathrm{X}$ \\
Indicator variables & & & $\mathrm{X}$ & $\mathrm{X}$ \\
$\quad$ for $F E$ deciles & & $\mathrm{X}$ & & $0.765^{* * *}$ \\
Controls & $0.582^{* * *}$ & $0.748^{* * *}$ & $0.622^{* * *}$ & $(0.040)$ \\
Constant & $(0.014)$ & $(0.040)$ & $(0.017)$ & 114,031 \\
& 114,031 & 114,031 & 114,031 & $5.2 \%$ \\
Observations & $0.7 \%$ & $4.6 \%$ & $1.3 \%$ & \\
$R^{2}$ & & & &
\end{tabular}

predicted to be related to investor bias. We now test whether the distraction effect can be used to form portfolios that take advantage of the stronger postearnings announcement drift after announcements on days with high distracting news.

At the end of each month from March 1995 until December 2004, we independently sort stocks into $5 \times 5$ portfolios based on their most recent earnings surprises within the last 3 months and the number of earnings announcements on the day of the earnings announcement. We then calculate equally weighted returns of each of the resulting $5 \times 5$ portfolios during the following month. Within each number-of-announcements quintile $(N R A N K)$, we form a hedge portfolio that is long the good news portfolio $(F E=5)$ and short the bad news portfolio $(F E=1)$ and compute the return of the hedge portfolio.

If investors underreact to earnings news, the good news portfolio will outperform the bad news portfolio. Therefore, the abnormal return of the hedge portfolio will be larger when there is stronger post-earnings announcement drift. 


\section{Table VII}

\section{Fama-French Alphas of Post-earnings Announcement Drift Portfolios}

At the end of each month from March 1995 until December 2004, we independently sort stocks into $5 \times 5$ groups based on their most recent quarterly earnings surprises within the last 3 months $(F E=1-5)$ and the number of earnings announcements on the day of the earnings announcement $(N R A N K=1-5)$. We calculate equally weighted returns of the resulting $5 \times 5$ portfolios during the following month. Within each number-of-announcements rank (NRANK), we form a hedge portfolio that is long the good news portfolio $(F E=5)$ and short the bad news portfolio $(F E=$ 1) to exploit post-earnings announcement drift. Alphas from time-series regressions of portfolio monthly returns (less the risk-free rate, except for the zero-cost hedge portfolios) on Fama-French three factors are reported with Newey-West standard errors with 12 lags in parentheses. The first row reports the alphas of the base post-earnings announcement drift portfolios, equally weighting firms in each earnings surprise quintile. The last row reports the alphas of hedge portfolios long the high-news-day portfolio $(N R A N K=5)$ and short the low-news-day portfolio $(N R A N K=1)$ within each earnings surprise quintile. ${ }^{*},{ }^{* *},{ }^{* * *}$ indicate significance at the $10 \%, 5 \%$, and $1 \%$ level, respectively.

\begin{tabular}{|c|c|c|c|c|c|c|}
\hline & \multicolumn{5}{|c|}{ Earnings Surprise Quintile } & \multirow[b]{2}{*}{$\begin{array}{c}F E 5-F E 1 \\
(\text { Good-Bad }\end{array}$} \\
\hline & $\begin{array}{c}F E=1 \\
(\text { Bad News })\end{array}$ & 2 & 3 & 4 & $\begin{array}{c}F E=5 \\
(\text { Good News })\end{array}$ & \\
\hline All & $\begin{array}{r}-0.57 \\
(0.36)\end{array}$ & $\begin{array}{c}-0.53^{* * *} \\
(0.20)\end{array}$ & $\begin{array}{r}-0.12 \\
(0.14)\end{array}$ & $\begin{array}{c}0.04 \\
(0.14)\end{array}$ & $\begin{array}{l}0.75^{\text {*** }} \\
(0.26)\end{array}$ & $\begin{array}{l}1.32^{\text {*** }} \\
(0.26)\end{array}$ \\
\hline NRANK 1 & $\begin{array}{c}-0.21 \\
(0.42)\end{array}$ & $\begin{array}{c}-0.53^{* *} \\
(0.22)\end{array}$ & $\begin{array}{c}-0.17 \\
(0.21)\end{array}$ & $\begin{array}{c}0.04 \\
(0.21)\end{array}$ & $\begin{array}{c}0.56^{* *} \\
(0.24)\end{array}$ & $\begin{array}{c}0.77 \\
(0.47)\end{array}$ \\
\hline 2 & $\begin{array}{c}-1.10^{* * *} \\
(0.37)\end{array}$ & $\begin{array}{c}-0.56^{* *} \\
(0.24)\end{array}$ & $\begin{array}{c}-0.04 \\
(0.21)\end{array}$ & $\begin{array}{c}-0.23 \\
(0.18)\end{array}$ & $\begin{array}{c}0.45 \\
(0.28)\end{array}$ & $\begin{array}{l}1.55^{* * *} \\
(0.26)\end{array}$ \\
\hline 3 & $\begin{array}{c}-0.51 \\
(0.43)\end{array}$ & $\begin{array}{c}-0.61^{* * *} \\
(0.23)\end{array}$ & $\begin{array}{c}0.02 \\
(0.17)\end{array}$ & $\begin{array}{c}-0.02 \\
(0.15)\end{array}$ & $\begin{array}{c}0.70^{* *} \\
(0.30)\end{array}$ & $\begin{array}{l}1.22^{* * *} \\
(0.37)\end{array}$ \\
\hline 4 & $\begin{array}{c}-0.16 \\
(0.50)\end{array}$ & $\begin{array}{c}-0.56^{* *} \\
(0.25)\end{array}$ & $\begin{array}{c}-0.26 \\
(0.16)\end{array}$ & $\begin{array}{c}0.32 \\
(0.20)\end{array}$ & $\begin{array}{l}0.94^{* * * *} \\
(0.34)\end{array}$ & $\begin{array}{l}1.09^{* * *} \\
(0.40)\end{array}$ \\
\hline NRANK5 & $\begin{array}{r}-0.60^{*} \\
(0.34)\end{array}$ & $\begin{array}{c}-0.44^{* * *} \\
(0.17)\end{array}$ & $\begin{array}{r}-0.15 \\
(0.14)\end{array}$ & $\begin{array}{c}0.06 \\
(0.17)\end{array}$ & $\begin{array}{l}1.04^{* * *} \\
(0.34)\end{array}$ & $\begin{array}{l}1.64^{* * *} \\
(0.31)\end{array}$ \\
\hline $\begin{array}{l}\text { NRANK5 } \\
-N R A N K 1\end{array}$ & $\begin{array}{c}-0.38 \\
(0.33)\end{array}$ & $\begin{array}{c}0.09 \\
(0.16)\end{array}$ & $\begin{array}{c}0.03 \\
(0.20)\end{array}$ & $\begin{array}{c}0.02 \\
(0.21)\end{array}$ & $\begin{array}{r}0.48^{*} \\
(0.24)\end{array}$ & $\begin{array}{r}0.86^{*} \\
(0.47)\end{array}$ \\
\hline
\end{tabular}

Because quarterly earnings announcements during the preceding 3 months are used to form portfolios, the strategy uses most of the CRSP stocks with quarterly earnings information and captures up to 3 months of post-announcement returns. We measure monthly abnormal performance of the portfolio using alphas from a time-series regression of the portfolio return (less the risk-free rate except for the zero-cost hedge portfolios) on the Fama-French three factors.

Table VII shows that a trading strategy designed to exploit post-earnings announcement drift achieves a higher abnormal return when implemented on earnings announcements that occur on high-news days than on low-news days. The Good minus Bad earnings news hedge portfolio three-factor alpha is quite substantial (1.64\% per month) and significant at the $1 \%$ level for the highnews portfolio $(N R A N K=5)$. The alpha is only $0.77 \%$ and insignificant for the low-news portfolio $(N R A N K=1)$. In other words, there is no discernible 
post-earnings announcement drift when there is little competing news that distracts investors from the earnings news. The hedge portfolio returns across NRANK are not monotonic, possibly due to small firm sizes in the second number-of-announcements quintile (Table I, Panel B).

The "fund-of-fund" portfolio, which is formed by going long the high-news hedge portfolio and short the low-news hedge portfolio, has a three-factor alpha of $0.86 \%$ that is significant at the $10 \%$ level. This indicates that the postannouncement drift portfolio strategy using high-news-day announcements earns marginally higher returns than that using low-news-day announcements.

The portfolio strategy findings confirm the univariate and regression results that post-earnings announcement drift is stronger for earnings announcements made on high-news days than low-news days. The portfolio findings also indicate that, in the absence of transactions costs, the amount of distraction on the day of the earnings announcement is useful information for an investor who seeks to exploit post-earnings announcement drift to achieve superior returns.

\section{Comparative Statics of the Distraction Effect}

\section{A. Which Competing Announcements Are More Distracting?}

So far we have treated all announcements by other firms alike. However, a competing announcement does not necessarily distract. If two firms are closely related or belong to the same sector, an announcement by one firm might attract attention to the other by drawing the investor's attention to the sector. For example, Google's earnings announcements may attract investors' attention to earnings announcements by other internet portal firms (but distract investor attention from the announcements of unrelated firms). On the other hand, for investors who already specialize in a particular sector, an announcement outside the sector cannot draw their attention to it. For these investors, the announcements of related firms in the sector should be more distracting. Which effect dominates (greater distraction for related announcements, or for unrelated announcements) is therefore an empirical question.

We identify firm relatedness by whether they are in the same industry using the Fama-French 10 industry classification. The number of related announcements is the number of earnings announcements by same-industry firms; the number of unrelated announcements is the number of announcements by firms in other industries. Because Industry 10 in the Fama-French classification is defined as "others" that do not belong to any of the predefined categories, we limit the analysis to Industries 1-9.

In the regression analyses, we interact the earnings surprise decile rank $(F E)$ with the number of related announcements decile (\#RelatedNews) and the number of unrelated announcements decile (\#UnrelatedNews) to test the effect of related and unrelated announcements on investor reactions to earnings news. The first set of regressions in Table VIII shows that $F E \times$ \#RelatedNews is not significant and $F E \times \#$ UnrelatedNews is significant in both regressions. The results suggest that unrelated news distracts investors more strongly than 


\section{Table VIII}

\section{Which Competing Announcements Are More Distracting?}

We split competing announcements into two groups and compare the distraction effect of different types of competing announcements. We consider three different splits: (1) industry related vs. unrelated announcements, (2) big vs. small absolute earnings surprises, and 3) large vs. small firm announcements. $F E$ is the earnings surprise decile $(F E=1$ : lowest, 10: highest) based on quarterly sorts by forecast errors. In the first set of regressions, we calculate the number of quarterly earnings announcements by the same industry firms ("related announcements") and the number of quarterly earnings announcements by firms in other industries ("unrelated announcements") using the Fama-French 10 industry classification, after excluding firms in Industry 10 ("Others"). \#RelatedNews (\#UnrelatedNews) is the decile rank of the number of related (unrelated) announcements (10: highest, 1: lowest) announcements based on quarterly sorts by the number of related (unrelated) announcements. In the second set of regressions, we split announcements in each calendar quarter into two groups by the absolute earnings surprises (small vs. big news). \#SmallNews (\#BigNews) is the decile rank of the number of competing announcements with small (big) absolute earnings surprise. In the third set, we split announcements into two groups by firm size (small vs. large firms). \#SmFirmNews (\#LgFirmNews) is the decile rank of the number of competing announcements by small (large) firms. Control variables include size and book-to-market deciles, log (1 + \# Analysts), Reporting Lag, Reporting Lag squared and cubed, institutional ownership (IO), Earnings Volatility, Earnings Persistence, Share Turnover, and indicator variables for year, month, day of week, and Fama-French 10 industry classification. See Section III.A for variable definitions. All control variables are interacted with FE. Standard errors adjusted for heteroskedasticity and clustering by the day of announcement are in parentheses. ${ }^{*}, * *, * *$ indicate significance at the $10 \%, 5 \%$, and $1 \%$ level, respectively.

\begin{tabular}{|c|c|c|c|c|c|c|}
\hline & \multicolumn{2}{|c|}{$\begin{array}{c}\text { Split by Industry } \\
\text { Relatedness }\end{array}$} & \multicolumn{2}{|c|}{$\begin{array}{l}\text { Split by Absolute } \\
\text { Earnings Surprise }\end{array}$} & \multicolumn{2}{|c|}{ Split by Firm Size } \\
\hline & $C A R[0,1]$ & $C A R[2,61]$ & $C A R[0,1]$ & $C A R[2,61]$ & $C A R[0,1]$ & $C A R[2,61]$ \\
\hline$F E$ & $\begin{array}{l}1.046^{* * *} \\
(0.111)\end{array}$ & $\begin{array}{l}0.787^{* *} \\
(0.368)\end{array}$ & $\begin{array}{l}1.006^{* * *} \\
(0.105)\end{array}$ & $\begin{array}{l}1.121^{* * *} \\
(0.330)\end{array}$ & $\begin{array}{l}0.974^{* * *} \\
(0.105)\end{array}$ & $\begin{array}{l}1.112^{* * *} \\
(0.324)\end{array}$ \\
\hline$F E \times \#$ RelatedNews & $\begin{array}{c}-0.004 \\
(0.008)\end{array}$ & $\begin{array}{c}-0.002 \\
(0.028)\end{array}$ & & & & \\
\hline$F E \times \#$ UnrelatedNews & $\begin{array}{l}-0.016^{* *} \\
(0.007)\end{array}$ & $\begin{array}{l}0.056^{* *} \\
(0.026)\end{array}$ & & & & \\
\hline$F E \times \# B i g N e w s$ & & & $\begin{array}{c}-0.017 \\
(0.010)\end{array}$ & $\begin{array}{l}0.099^{* * *} \\
(0.030)\end{array}$ & & \\
\hline$F E \times \#$ SmallNews & & & $\begin{array}{c}0.001 \\
(0.011)\end{array}$ & $\begin{array}{c}-0.048 \\
(0.030)\end{array}$ & & \\
\hline$F E \times \# L g F i r m N e w s$ & & & & & $\begin{array}{c}0.003 \\
(0.008)\end{array}$ & $\begin{array}{r}-0.006 \\
(0.026)\end{array}$ \\
\hline$F E \times \#$ SmFirmNews & & & & & $\begin{array}{l}-0.016^{* * *} \\
(0.006)\end{array}$ & $\begin{array}{l}0.048^{* *} \\
(0.022)\end{array}$ \\
\hline $\begin{array}{l}\text { Controls, interacted } \\
\text { with } F E\end{array}$ & $\mathrm{X}$ & $\mathrm{X}$ & $\mathrm{X}$ & $\mathrm{X}$ & $\mathrm{X}$ & $\mathrm{X}$ \\
\hline Constant & $\begin{array}{l}-5.702^{* * *} \\
(0.660)\end{array}$ & $\begin{array}{l}-7.731^{* * *} \\
(2.231)\end{array}$ & $\begin{array}{l}-5.321^{* * *} \\
(0.631)\end{array}$ & $\begin{array}{l}-8.429^{* * *} \\
(2.011)\end{array}$ & $\begin{array}{l}-5.101^{* * *} \\
(0.615)\end{array}$ & $\begin{array}{c}-8.594^{* * *} \\
(1.986)\end{array}$ \\
\hline Observations & 89,095 & 89,095 & 112,839 & 112,839 & 112,839 & 112,839 \\
\hline$R^{2}$ & $6.4 \%$ & $1.4 \%$ & $6.2 \%$ & $1.1 \%$ & $6.2 \%$ & $1.1 \%$ \\
\hline
\end{tabular}


related news, which is plausible if a majority of investors try to diversify their portfolios by holding stocks across different sectors.

Because extreme surprises are more likely to be distracting than small surprises, we compare the distraction effect of big and small competing news. All announcements in each calendar quarter are split into two equal-sized groups (big vs. small) based on the absolute earnings surprise, where \#SmallNews is the decile rank of the number of competing announcements with relatively small absolute earnings surprises and \#BigNews is the decile rank of the number of competing announcements with relatively big absolute earnings surprises. The second set of regressions (columns (3) and (4)) in Table VIII shows that the coefficient on $F E \times \# B i g N e w s$ is -0.017 but not significant for $C A R[0,1]$ and 0.099 , statistically significant at the $1 \%$ level, for $C A R[2,61]$. However, the coefficient on $F E \times \#$ SmallNews is insignificant in both regressions, suggesting that big surprises have a much stronger distraction effect than small surprises. ${ }^{9}$

Similar to the big versus small news comparison, in each calendar quarter we split announcements into two equal-sized groups based on firm size, where \#SmFirmNews is the decile rank of the number of competing announcements that belong to the smaller size group and \#LgFirmNews the decile rank of the number of competing announcements that belong to the larger size group. We initially expected large firm announcements to be more distracting, but the results suggest the opposite; in the third set of regressions of Table VIII, the coefficient estimates on $F E \times \#$ SmFirmNews are all significant while those on $F E \times \# L g F i r m N e w s$ are not, suggesting that the effect of the number of small firm announcements dominates that of the number of large firm announcements. This is probably because disproportionately more small firm announcements are extreme surprises compared to those of large firms. We find that $43 \%$ of small firm announcements are in absolute earnings surprise Deciles 9 and 10 , while only $14 \%$ of large firm announcements are in Deciles 9 and 10 . If extreme earnings surprises are more distracting, we are likely to find a stronger distraction effect by small firm announcements that tend to be more extreme. A further possible explanation is based on our finding that industry-unrelated news is more distracting. Large firms tend to be more diversified than small firms, so ceteris paribus a large firm is more likely than a small firm to have some industry relatedness to the test firm.

After considering the separate impacts of industry relatedness, size of earnings news, and firm size, we consider the impact of all these variables contemporaneously in one regression to disentangle the different effects. In the regression analysis reported in the Internet Appendix, we include all split number of

\footnotetext{
${ }^{9}$ Both $F E \times \# B i g N e w s$ and $F E \times \#$ SmallNews are insignificant for the CAR $[0,1]$ regression (column (3)), with $F E \times \#$ BigNews marginally insignificant $(p=0.103)$. There are indications that $F E \times \# B i g N e w s$ is insignificant due to multicollinearity and reduced power in that regression: Both $F E \times \#$ BigNews and $F E \times \#$ SmallNews are significant when we include only one of them in the regression (reported in the Internet Appendix), and adding $F E \times \#$ SmallNews in the regression increases the standard error of $F E \times \#$ BigNews from 0.006 to 0.010 while the size of the coefficient estimate actually increases from -0.016 to -0.017 .
} 
announcements in the regression (\#RelatedNews \& \#UnrelatedNews, \#BigNews \& \#SmallNews, and \#SmFirmNews \& \#LgFirmNews) to explore whether the stronger distraction effect of small firm announcements is driven by the size of earnings news or industry relatedness. In the $C A R[2,61]$ regression, we find that $F E \times \#$ BigNews is highly significant at the $1 \%$ level, $F E \times \# L g F i r m N e w s$ is marginally significant at the $10 \%$ level, and all others are insignificant, suggesting that the effect of \#SmFirmNews is likely to be driven by the relatively bigger size of small firms' absolute earnings surprises. Unfortunately, the variables are sufficiently collinear that none of the split announcement variables are significant in the $C A R[0,1]$ regression.

\section{B. Distraction Effect across Firm Size and the Sign of Earnings News}

Past research on market reactions to earnings suggests that the effect of distraction may depend on the type of announcements and the type of firms. Previous studies (e.g., Bernard and Thomas (1989)) find that post-earnings announcement drift is stronger for smaller firms. Furthermore, if large firms inherently attract greater investor attention, then announcements by other firms will have relatively little distracting effect. For both reasons, we expect that among large firms, any distraction effects will be weaker and harder to detect.

Psychological forces such as negativity bias (a tendency to focus on bad news) and loss aversion suggest that people tend to find bad news more salient than good news, which could temper the effect of distraction upon reactions to bad news. Furthermore, previous studies have shown that there is asymmetry both in distribution of positive versus negative earnings surprises and in market responses to earnings surprises. DeGeorge, Patel, and Zeckhauser (1999) document that more earnings surprises are positive than negative (they are clustered at zero, with few small negative surprises), which suggests that a small negative earnings surprise is more surprising than a small positive one. Basu (1997) finds that stock returns are more sensitive to the size of positive earnings surprises than the size of negative earnings surprises. Because the reactions to earnings news are asymmetric, we cannot assume that distraction effects are symmetric for good and bad news earnings announcements. We therefore examine separately the effect of competing announcements for positive and negative earnings surprises.

Table IX shows the variation in the distraction effect across firm size and the sign of earnings surprise. The distraction effect is measured by the coefficient estimate on $F E \times N R A N K$, which is negative in the announcement return regression (weaker response for high-news-day announcements) and positive in the post-announcement return regression (stronger drift after highnews-day announcements). To test if the distraction effect differs between large and small firms, in each calendar quarter we split the sample into two equalsized groups based on firm size, and create the indicator variable LgFirm that takes the value of one for large firm announcements and zero for small firm announcements. In addition to the standard set of variables, we include 
Table IX

\section{Variation in the Distraction Effect across Firm Size and the Sign of Earnings News}

We examine how the distraction effect $(F E \times N R A N K)$ varies with firm size and the sign of earnings news. NRANK is the number-of-announcements deciles based on quarterly sorts by the number of announcements on the day of the announcement. In Regressions (1) and (2), $F E$ is the earnings surprise decile $(F E=1$ : lowest, 10: highest) based on quarterly sorts by forecast error. We split the sample into two groups by firm size (small vs. large) and create the indicator variable $L$ gFirm (one for large firms, zero for small firms). Regressions (1) and (2) include additional variables, $F E \times N R A N K \times L g F i r m, N R A N K \times L g F i r m, F E \times L g F i r m$, and LgFirm. Regressions (3) and (4) show estimates of piece-wise linear regressions, where we allow the return sensitivity to earnings news and the distraction effect to differ for positive surprises. $F E$ is the earnings surprise quantile, where negative earnings surprises are ranked into the first five quantiles (1-5), zero surprises are assigned to quantile 6 , and positive surprises are assigned to the top five quantiles, $7-11$. $F E_{p}$ is equal to $\operatorname{Max}(F E-6,0)$. Control variables include size and book-to-market deciles, $\log (1+\#$ Analysts), Reporting Lag, Reporting Lag squared and cubed, institutional ownership (IO), Earnings Volatility, Earnings Persistence, Share Turnover, and indicator variables for year, month, day of week, and Fama-French 10 industry classification. See Section III.A for variable definitions. All control variables are interacted with $F E$ and $F E_{p}$. Standard errors adjusted for heteroskedasticity and clustering by the day of announcement are in parentheses. ${ }^{*},{ }^{* *},{ }^{* * *}$ indicate significance at the $10 \%, 5 \%$, and $1 \%$ level, respectively.

\begin{tabular}{|c|c|c|c|c|}
\hline & $\begin{array}{c}(1) \\
C A R[0,1]\end{array}$ & $\begin{array}{c}(2) \\
C A R[2,61]\end{array}$ & $\begin{array}{c}(3) \\
C A R[0,1]\end{array}$ & $\begin{array}{c}(4) \\
C A R[2,61]\end{array}$ \\
\hline$F E$ & $\begin{array}{l}1.086^{* * * *} \\
(0.103)\end{array}$ & $\begin{array}{l}0.886^{* * *} \\
(0.343)\end{array}$ & $\begin{array}{l}0.441^{* *} \\
(0.210)\end{array}$ & $\begin{array}{l}1.859^{* * *} \\
(0.673)\end{array}$ \\
\hline$F E_{p}$ & & & $\begin{array}{l}0.961^{* * *} \\
(0.326)\end{array}$ & $\begin{array}{c}-1.564 \\
(1.080)\end{array}$ \\
\hline$F E \times N R A N K$ & $\begin{array}{l}-0.025^{* * *} \\
(0.008)\end{array}$ & $\begin{array}{l}0.069^{* *} \\
(0.027)\end{array}$ & $\begin{array}{c}0.004 \\
(0.011)\end{array}$ & $\begin{array}{l}0.075^{* *} \\
(0.037)\end{array}$ \\
\hline$F E_{p} \times N R A N K$ & & & $\begin{array}{r}-0.033^{*} \\
(0.018)\end{array}$ & $\begin{array}{r}-0.057 \\
(0.060)\end{array}$ \\
\hline$F E \times N R A N K \times L g F i r m$ & $\begin{array}{l}0.016^{* *} \\
(0.007)\end{array}$ & $\begin{array}{r}-0.031 \\
(0.026)\end{array}$ & & \\
\hline $\begin{array}{l}\text { Controls, interacted with } \\
\qquad F E \text { and } F E_{p}\end{array}$ & $\mathrm{X}$ & $\mathrm{X}$ & $\mathrm{X}$ & $\mathrm{X}$ \\
\hline Constant & $\begin{array}{c}-5.606^{* * *} \\
(0.612)\end{array}$ & $\begin{array}{c}-7.436^{* * *} \\
(2.101)\end{array}$ & $\begin{array}{c}-3.947^{* * *} \\
(1.041)\end{array}$ & $\begin{array}{c}-11.306^{* * *} \\
(3.403)\end{array}$ \\
\hline Observations & 112,839 & 112,839 & 112,839 & 112,839 \\
\hline$R^{2}$ & $6.2 \%$ & $1.1 \%$ & $6.3 \%$ & $1.5 \%$ \\
\hline
\end{tabular}

$F E \times N R A N K \times L g F i r m, F E \times L g F i r m, N R A N K \times L g F i r m$, and LgFirm in Regressions (1) and (2).

These regressions provide weak evidence that distraction affects firms with small market capitalizations more strongly. For example, $F E \times N R A N K \times$ LgFirm is positive and significant at the 5\% level in Regression 1 of Table IX, implying that the distraction effect on announcement date returns (negative $F E \times N R A N K$ ) is muted among larger firms. For post-announcement drift, 
$F E \times N R A N K \times L g F i r m$ is negative but insignificant in Regression $2 .{ }^{10}$ In results reported in the Internet Appendix, we find that the results are similar with analyst following or institutional ownership. There is weak evidence that the distraction effect is weaker among firms with greater analyst following or institutional ownership.

To test for asymmetry in the effects of distraction on market reactions to positive versus negative earnings surprises, we form earnings surprise quantiles following DellaVigna and Pollet (2009), where negative earnings surprises are ranked into five equal-sized groups and assigned to quantiles 1-5, zero surprises are assigned to quantile 6 , and positive surprises are assigned to quantiles 7-11. We estimate the following piece-wise linear model to allow the distraction effect as well as return sensitivity to change for positive earnings surprises

$$
C A R=a_{0}(X)+a_{1}(X) F E+a_{2}(X) F E_{p}+\varepsilon,
$$

where $F E$ is the earnings quantile and $F E_{p}$ is equal to $F E-6$ for positive surprises (quantiles 7-11) and zero otherwise $\left(F E_{p}=\operatorname{Max}(F E-6,0)\right)$. The regression coefficients and the intercept are modeled as functions of NRANK and the set of control variables. Thus, the specification allows the return sensitivity to earnings news and the distraction effect to be different for positive surprises. The interaction term $F E_{p} \times N R A N K$ will be significant if there is a reliable difference in the distraction effect for positive surprises compared to negative or zero surprises. ${ }^{11}$

We estimate the above regression model in columns (3) and (4) of Table IX. For the announcement period abnormal return, $C A R[0,1]$, the coefficient on $F E_{p}$ is positive and significant at the $1 \%$ level, indicating asymmetry in return responses to news. Distraction effects are tested by the interaction terms $F E \times$ $N R A N K$ and $F E_{p} \times N R A N K$. The coefficient on $F E_{p} \times N R A N K$ is negative and significant at the $10 \%$ level, which indicates that the distraction effect is weakly stronger for positive earnings surprises than for negative surprises. However, for post-earnings announcement drift there is no evidence of asymmetry in the drift and distraction effects; the coefficient on $F E_{p} \times N R A N K$ (and on $F E_{p}$ ) is insignificant in the $C A R[2,61]$ regression. Overall, therefore, the evidence on possible asymmetry of the distraction effect is mixed.

\section{Concluding Remarks}

A mainstay of behavioral asset pricing theory is the idea that several important return anomalies represent market underreactions to information. A leading explanation for such underreaction is that investors with limited attention neglect newly arriving information signals. Consistent with this theory,

\footnotetext{
${ }^{10}$ When we use $F E \times N R A N K \times S I Z E(S I Z E$ : size decile), we find that the distraction effect decreases with the size decile (significant at the $10 \%$ level) for both announcement and postannouncement abnormal returns.

${ }^{11}$ The results are similar if we drop zero surprises from the sample.
} 
several recent empirical papers provide evidence suggesting that limited attention affects asset prices.

However, most work on attention documents the neglect of public signals, the extent to which salient publicity draws more attention to some signal, and the effects on market reactions of general conditions (market return, volume, timeof-day, or day of week) that proxy for attention versus inattention. Implicit in such tests is the idea that other calls on cognitive resources overwhelm investors, limiting investors' response to the public signal in question.

This paper provides new insight into the validity of the attention hypothesis by testing directly whether extraneous news distracts investors, causing market prices to underreact to relevant news. Our tests focus on the competing information signals that draw investor attention away from a given firm. We propose the investor distraction hypothesis, which holds that the arrival of extraneous earnings news causes trading volume and market prices to react sluggishly to relevant news about a firm. Specifically, we examine how the number of earnings announcements by other firms affects a firm's volume, announcement period return, and post-event return reactions to an earnings surprise.

Our evidence indicates that the presence of a large number of competing earnings announcements by other firms is associated with a weaker announcement date price reaction to a firm's own earnings surprise, a lower volume reaction, and stronger subsequent post-earnings announcement drift. A portfolio trading strategy that takes into account the information both in earnings surprises and the number of competing earnings announcements occurring on the same day as those surprises indicates that distraction effects are economically substantial. Competing announcements made by firms in other industries and big earnings surprises have a stronger distraction effect than announcements by same-industry firms and small surprises, respectively. There is some indication that distraction affects market reactions to positive earnings surprises and announcements by small firms more strongly than reactions to negative surprises and large firm announcements.

These findings are consistent with the investor distraction hypothesis. Furthermore, they indirectly suggest that investors' limited attention may drive the basic anomaly, post-earnings announcement drift. More broadly, this evidence raises the possibility that limited attention is the source of the general pattern documented in several studies of underreaction to a variety of public corporate news events. It also raises the possibility that other kinds of distracting information (e.g., the arrival of irrelevant non-earnings information about either the given firm or other firms) can contribute to market underreactions to relevant information.

\section{REFERENCES}

Bagnoli, Mark, Michael B. Clement, and Susan G. Watts, 2005, Around-the-clock media coverage and the timing of earnings announcements, Working paper, Purdue University.

Baker, A. G., Pierre Mercier, Frederic Valleettourangeau, Robert Frank, and Maria Pan, 1993, Selective associations and causality judgments-Presence of a strong causal factor may reduce 
judgements of a weaker one, Journal of Experimental Psychology-Learning, Memory and Cognition 19, 414-432.

Barber, Brad, and Terrance Odean, 2000, Trading is hazardous to your wealth: The common stock investment performance of individual investors, Journal of Finance 55, 773-806.

Barber, Brad, and Terrance Odean, 2008, All that glitters: The effect of attention and news on the buying behavior of individual and institutional investors, Review of Financial Studies 21, $785-818$.

Basu, Sudipta, 1997, The conservatism principle and the asymmetric timeliness of earnings, Journal of Accounting and Economics 24, 3-37.

Bernard, Victor L., and Jacob K. Thomas, 1989, Post-earnings-announcement drift: Delayed price response or risk premium? Journal of Accounting Research 27, (Supplement), 1-48.

Brennan, Michael J., Narasimhan Jegadeesh, and Bhaskaran Swaminathan, 1993, Investment analysis and the adjustment of stock prices to common information, Review of Financial Studies 6, 799-824.

Brenner, Lyle A., Derek J. Koehler, and Amos Tversky, 1996, On the evaluation of one-sided evidence, Journal of Behavioral Decision Making 9, 59-70.

Broadbent, Donald E., 1958, Perception and Communication (Pergamon Press, New York, NY).

Busemeyer, Jerome R., In Jae Myung, and Mark A. McDaniel, 1993, Cue competition effectsEmpirical tests of adaptive network learning models, Psychological Science 4, 190-195.

Chambers, Anne E., and Stephen H. Penman, 1984, Timeliness of reporting and the stock price reaction to earnings announcements, Journal of Accounting Research 22, 21-47.

Cherry, E. Colin, 1953, Some experiments on the recognition of speech, with one and two ears, Journal of the Acoustical Society of America 25, 975-979.

Cohen, Lauren, and Andrea Frazzini, 2008, Economic links and predictable returns, Journal of Finance 63, 1977-2011.

Coval, Joshua D., and Tyler Shumway, 2005, Do behavioral biases affect prices? Journal of Finance $61,1-34$.

Damodaran, Aswath, 1989, The weekend effect in information: A study of earnings and dividend announcements, Review of Financial Studies 4, 607-623.

DeGeorge, Francois, Jayendu Patel, and Richard Zeckhauser, 1999, Earnings management to exceed thresholds, Journal of Business 72, 1-34.

DellaVigna, Stefano, and Joshua M. Pollet, 2007, Demographics and industry returns, American Economic Review 97, 1167-1702.

DellaVigna, Stefano, and Joshua M. Pollet, 2009, Investor inattention and Friday earnings announcements, Journal of Finance 64, 709-749.

Desai, Hemang, and Prem C. Jain, 1997, Long-run common stock returns following stock splits and reverse splits, Journal of Business 70, 409-434.

Dichev, Ilia, and Joseph Piotroski, 2001, The long-run stock returns following bond ratings changes, Journal of Finance 56, 173-203.

Francis, Jennifer, Donald Pagach, and Jens Stephan, 1992, The stock market response to earnings announcements released during trading versus nontrading periods, Journal of Accounting Research 30, 165-184.

Frazzini, Andrea, 2006, The disposition effect and underreaction to news, Journal of Finance 61, 2017-2046.

Grossman, Sanford J., and Joseph E. Stiglitz, 1976, Information and competitive price systems, American Economic Review 66, 246-253.

Hirshleifer, David, and Siew Hong Teoh, 2003, Limited attention, information disclosure, and financial reporting, Journal of Accounting and Economics 36, 337-386.

Hirshleifer, David, and Siew Hong Teoh, 2005, Limited investor attention and stock market misreactions to accounting information, Working paper, Ohio State University.

Hirshleifer, David, James Myers, Linda Myers, and Siew Hong Teoh, 2008, Do individual investors drive post-earnings announcement drift? Direct evidence from personal trades, Accounting Review 83, 1521-1550.

Ho, Thomas, and Roni Michaely, 1988, Information quality and market efficiency, Journal of Financial and Quantitative Analysis 5, 357-386. 
Hong, Harrison, Terence Lim, and Jeremy Stein, 2000, Bad news travels slowly: Size, analyst coverage and the profitability of momentum strategies, Journal of Finance 55, 265-295.

Hong, Harrison, Walter Torous, and Rossen Valkanov, 2007, Do industries lead stock markets? Journal of Financial Economics 83, 367-396.

Hou, Kewei, 2007, Industry information diffusion and the lead-lag effect in stock returns, Review of Financial Studies 20, 1113-1138.

Hou, Kewei, and Tobias Moskowitz, 2005, Market frictions, price delay, and the cross-section of expected returns, Review of Financial Studies 18, 981-1020.

Hou, Kewei, Lin Peng, and Wei Xiong, 2008, A tale of two anomalies: The implication of investor attention for price and earnings momentum, Working paper, Ohio State University.

Huberman, Gur, and Tomer Regev, 2001, Contagious speculation and a cure for cancer, Journal of Finance 56, 387-396.

Ikenberry, David, Josef Lakonishok, and Theo Vermaelen, 1995, Market underreaction to open market share repurchases, Journal of Financial Economics 39, 181-208.

James, William, 1890, The Principles of Psychology, vol. 1 (Henry Holt, New York), 403-404.

Jegadeesh, Narasimhan, and Sheridan Titman, 1993, Returns to buying winners and selling losers: Implications for stock market efficiency, Journal of Finance 48, 65-91.

Kaniel, Ron, Gideon Saar, and Sheridan Titman, 2008, Individual investor trading and stock returns, Journal of Finance 63, 273-310.

Klibanoff, Peter, Owen Lamont, and Thierry A. Wizman, 1998, Investor reaction to salient news in closed-end country funds, Journal of Finance 53, 673-699.

Kothari, S. P., 2001, Capital market research in accounting, Journal of Accounting and Economics $31,105-231$.

Kruschke, John K., and Mark K. Johansen, 1999, A model of probabilistic category learning, Journal of Experimental Psychology: Learning, Memory, and Cognition 25, 1083-1119.

Loughran, Tim, and Jay Ritter, 1995, The new issues puzzle, Journal of Finance 50, $23-52$.

McLeod, Peter, 1977, Parallel processing and the psychological refractory period, Acta Psychologica 41, 381-391.

Moray, Neville, 1959, Attention in dichotic listening: Affective cues and the influence of instructions, Quarterly Journal of Experimental Psychology 11, 56-60.

Pashler, Harold, and James C. Johnston, 1998, Attentional limitations in dual-task performance, in H. Pashler, ed.: Attention (Psychology Press/Erlbaum Taylor \& Francis, Hove, UK).

Peng, Lin, 2005, Learning with information capacity constraints, Journal of Financial and Quantitative Analysis 40, 307-329.

Peng, Lin, and Wei Xiong, 2006, Investor attention, overconfidence and category learning, Journal of Financial Economics 80, 563-602.

Pollet, Joshua M., 2005, Predicting asset returns with expected oil price changes, Working paper, University of Illinois at Urbana-Champaign.

Simons, Daniel J., and Christopher F. Chabris, 1999, Gorillas in our midst: Sustained in attentional blindness for dynamic events, Perception 28, 1059-1074.

Simons, Daniel J., and Daniel T. Levin, 1997, Change blindness, Trends in Cognitive Sciences 1, 261-267.

Stroop, J. Ridley, 1935, Studies of interference in serial verbal reactions, Journal of Experimental Psychology 28, 643-662.

Treisman, Ann M., and Alison Davies, 1973, Dividing attention to ear and eye, in Sylvan Kornblum, ed.: Attention and Performance IV (Academic Press, New York).

Tversky, Amos, and Daniel Kahneman, 1981, The framing of decisions and the psychology of choice, Science 211, 453-458. 